\title{
Mobile Object Markers in Moro: The Role of Tone
}

\author{
Peter Jenks \\ Sharon Rose \\ University of California, Berkeley University of California, San Diego
}

Object markers alternate between prefix and suffix position in the Thetogovela dialect of Moro, an underdocumented Kordofanian language of Sudan. Although the alternation appears to depend on the morphosyntactic category of verb forms, we show that it actually follows from the tone properties of these verb forms. Verb stems which are usually marked with a default, phonologically predictable leftmost high tone select object marker prefixes. The high-toned object prefix appears inside the stem, and its high tone serves as the default tone of the stem, obviating the need for inserted high tone. Verb stems which impose a particular melodic tone pattern select object marker suffixes. High-toned object markers are incompatible with melodic tone patterns, and cannot surface as prefixes within the stem. The data are analyzed as a case of phonology conditioning prefix placement and overriding standard suffix position. Although such phonologically determined mobile affixes are rare in the world's languages, the Moro case provides a new case of affix mobility based on a novel property, tone, and it underscores the need to incorporate such cases into the architecture of grammatical systems.

1. INTRODUCTION. The position of affixes within a word is correlated with a variety of different factors. On the one hand, morphosyntactic analyses relate affix position with syntactic derivation (Baker 1985), reflected in scope relationships (Rice 2000). On the other hand, in some languages, the positions of affixes are fixed relative to one another, sometimes violating scope relationships (Hyman 2003, Caballero 2010), and motivating the use of templates or fixed order stipulations (Inkelas 1993, Hyman 2003, Good 2007). There are also cases in which phonological factors appear to impact affix or clitic position, often driven by syllable structure (Fulmer 1991, Noyer 1994, Hargus and Tuttle 1997, Kim 2008) or stress (Caballero 2010). 
In two cases in particular, Afar (Fulmer 1991, Rucart 2006) and Huave (Noyer 1994, Kim 2008, 2010), a small set of affixes may appear as either a prefix or a suffix depending on syllable structure and whether the stem begins with a consonant or vowel, cases which has been termed MOBILE AFFIXATION (Noyer 1994). For example, in San Francisco del Mar Huave, the completive affix /t/ is a suffix in (1a), but a prefix in (1b) (Kim 2008, 2010):
(1) a. $\quad[$ mojk-o]-t
b. $\quad t-[e-m o j k-o-r]$
face.down-V-CP
CP-2-face.down-V-2I
's/he lay face down'
'you (sg.) lay face down'

Kim argues persuasively that the position of this affix and five other monoconsonantal affixes is determined by syllable structure. The affixes are prefixes if the stem begins with a vowel and ends in a consonant. Otherwise, they are suffixes. The analysis she offers depends on a conception of the phonology-morphology interface in which phonological constraints can outrank morphological constraints of affix placement, the $\mathrm{P}$ (honology) >> $\mathrm{M}$ (orphology) approach of McCarthy and Prince (1993). Noyer (1994) proposes a similar, but less detailed, analysis for San Mateo del Mar Huave. Other researchers have challenged the P >> M model, arguing that for infixation (Yu 2007a,b) and phonologically conditioned suppletive allomorphy (Paster 2006, 2009), a more constrained and explanatory analysis is one in which morphology precedes phonology and affix position is determined by GENERALIZED PHONOLOGICAL SUBCATEGORIZATION, in which affixes can subcategorize for a phonological constituent. One of the main arguments for this latter model is that while affix position may have a phonologicallydetermined position, it is not always phonologically optimizing in the output.

Nevertheless, mobile affixes of the type in (1), pose a problem for generalized subcategorization analyses, since there is no unified subcategorization - either one has to assume a single affix with competing subcategorization frames (Stump 1993) or two segmentally identical affixes with the same meaning but different subcategorization frames (Paster 2009). See further discussion in $§ 7$. Moreover, there is some skepticism as to whether phonologicallyconditioned mobile affixes even exist. Paster (2005) reanalyzes several cases in terms of morphological templatic positions or local metathesis, while Wolf (2008) questions whether the Afar mobile affix case is phonologically determined. Since mobile affix examples are rare, these type of treaments are deemed preferable to the option of allowing phonological constraints to 
determine morphological position. Given the problematic status of phonologically conditioned mobile affixation, new cases would lend credence to this rare breed, particularly if the phonological factors conditioning the affix position were of a different variety.

In this paper, we introduce a novel case of phonologically conditioned mobile affixation in which tone is the determining factor. In the Thetogovela dialect of Moro, a Kordofanian language spoken in the Nuba Mountains of Sudan, incorporated object pronouns, or object markers, are positioned as either prefixes or suffixes on the verb depending on 1) the tone patterns of the verb stem and 2) the tone of the object markers themselves. In the aspectual forms in (2a-b), high tone appears at the left edge of the verb root as shown for váléð 'pull' and tómbað 'tickle'. In these forms, the $2 \mathrm{SG}$ object marker $\boldsymbol{\eta} \boldsymbol{a}$ a appears as a prefix. When the object marker is present, high tone is not realized on the root. High tone is marked with a diacritic accent $(\dot{a})$ and low tone is unmarked. All data are from our notes. ${ }^{1}$

(2)

\begin{tabular}{|c|c|c|}
\hline & no object marker & w/2sg object marker \\
\hline \multirow[t]{5}{*}{ a. proximal imperfective } & g-a-vóléð-a & g-a-クá-vəleð-a \\
\hline & g-a-tfómbəð-a & g-a-ıá-tyombəð-a \\
\hline & SM.CL-RTC-root-IPFV & SM.CL-RTC-2SG.OM-root-IPFV \\
\hline & '(s)he is pulling here' & '(s)he is pulling you here' \\
\hline & '(s)he is tickling here' & '(s)he is tickling you here' \\
\hline \multirow[t]{5}{*}{ b. consecutive imperfective } & t-án- ${ }^{\downarrow}$ váléd- ${ }^{\star}$ ó & ț-áy- ${ }^{+}$yá-vəleð-ó \\
\hline & t-áy- ${ }^{\star}$ tómbəð- ${ }^{\star}$ ó & t-áy- ’’á-tyombəð-ó \\
\hline & COMP-3SGSM-root-CONS.IPFV & COMP-3SGSM-2SG.OM-root-CONS.IPFV \\
\hline & 'then (s)he is pulling' & 'then (s)he is pulling you' \\
\hline & 'then (s)he is tickling' & 'then (s)he is tickling you' \\
\hline
\end{tabular}

In contrast, in the aspectual forms in (3a-b), high tone does not appear on the root, but on the aspectual affixes. The object marker appears as a suffix with these forms.

\begin{tabular}{lll}
\hline no object marker & w/2sg object marker & \\
\hline a. $\quad$ distal imperfective & g-á-vəleð-ó & g-á-vəleð-ó-ná
\end{tabular}

${ }^{1}$ The initial noun class marker/g-/ of the verb is realized as $[\mathrm{k}]$ in phrase-initial position. Verbs in isolation begin with $[\mathrm{k}]$. We transcribe $[\mathrm{g}]$ here, although in other work we have used $[\mathrm{k}]$. 


\begin{tabular}{|c|c|c|}
\hline \multirow{9}{*}{ b. perfective } & g-á-tfombəð-ó & g-á-tரombəð-á-ná \\
\hline & SM.CL-DIST.IPFV-root-DIST.IPFV & SM.CL-DIST.IPFV-root-DIST.IPFV-2SG.OM \\
\hline & '(s)he is pulling there' & '( $\mathrm{s})$ he is pulling you there' \\
\hline & '(s)he is tickling there' & '( $\mathrm{s})$ he is tickling you there' \\
\hline & g-a-vəleð-ó & g-a-vəleð-ó-yá \\
\hline & g-a-tfombəð-ó & g-a-țombəð-ว́-yá \\
\hline & SM.CL-RTC-root-PFV & SM.CL-RTC-root-PFV-2SG.OM \\
\hline & '(s)he pulled there' & '(s)he pulled you there' \\
\hline & '(s)he tickled there' & '(s)he tickled you there' \\
\hline
\end{tabular}

The same pattern holds for other high-toned object markers, but when an object marker is lowtoned, as with the 3PL $-l o$, no variable positioning is found. Furthermore, high tone is found on the root in the forms with -lo in (4a-b), just as in the forms with no object marker.

\begin{tabular}{|c|c|c|c|}
\hline & no object marker & $w / 3 p l$ object marker & \\
\hline \multirow[t]{2}{*}{ a. } & proximal imperfective & g-a-vóléð-a & g-a-vóléð-a-lo \\
\hline & & g-a-tfómbəð-a & g-a-tfómbəð-a-1o \\
\hline \multirow[t]{2}{*}{ b. } & consecutive imperfective & t-áy-váléð-ó & ț-áy-váléð-á-1o \\
\hline & & t-áy-tfómbəð-ó & t-áy-tfómbəd-á-1o \\
\hline \multirow[t]{2}{*}{ c. } & distal imperfective & g-á-vəleð-ó & g-á-vəleð-á-lo \\
\hline & & g-á-țombəð-ó & g-á-tfombəð-á-1o \\
\hline \multirow[t]{2}{*}{ d. } & perfective & g-a-vəleð-ó & g-a-vəleð-á-1o \\
\hline & & g-a-t5ombəð-ó & g-a-tfombəð-ว́-1o \\
\hline
\end{tabular}

In this article, we argue that tone provides a better synchronic explanation for the variable position of the object markers than one based on morphosyntactic features of the verb. The distribution of tone on the verb stem as well as the tone of the object marker determines the position of the object marker. Moreover, we will argue that when the object marker appears as a prefix, it appears in a position which is phonologically optimizing according to independently motivated constraints on $\mathrm{H}$ tone distribution within the stem. As such, we conclude that the placement of Moro object markers represent a bona fide example of phonologically conditioned 
affix positioning, and hence that the interface between phonology, morphology and syntax should be able to accommodate such phenomena.

This paper is organized as follows. In $\S 2$, the basic data are introduced, illustrating the positions of the object markers and demonstrating how no cohesive analysis based on morphosyntactic properties can be responsible for their variable position. In $\S 3$, we present the tone patterns of Moro verb stems, and motivate domains of tone assignment. We show how the position of the object marker correlates with two different classes of tone patterns: prefix object markers occur with default tone and suffix object markers with melodic tone, both tone patterns distributed within the inflectional stem domain. In $\S 4$, we present a formal analysis. In $\S 5$, we present data from non-mobile object markers and double object markers, and show how their positions follow straightforwardly from the analysis developed. In $§ 6$ we demonstrate cases in which tone distribution occurs within the larger verb stem, but fails to affect the position of the object markers. In $\S 7$ we argue that alternatives fail to account for the attested pattern in Moro, including approaches based on phonologically conditioned spell-out of syntactic movement, the process of Local Dislocation within the Distributed Morphology framework, and phonological subcategorization. We also briefly review other cases of phonologically-conditioned affix position, arguing for the superiority of the $\mathrm{P}>>\mathrm{M}$ analysis.

2. THE VARIABLE POSITION OF OBJECT MARKERS. Moro object markers (OM) appear in two positions on the verb stem - preceding the root and iterative prefix, or following the aspect/mood/deixis (AMD) vowel. In (5) we illustrate the location of the OMs within the basic templatic structure of the Moro verb: ${ }^{2}$

Moro verb structure and position of OMs: COMP-SM-CLASS-CLAUSE-AMD-OM/PROG-ITER-ROOT-EXT-AMD-PL-OM-INST-LOC

\footnotetext{
${ }^{2}$ Abbreviations: $\mathrm{AMD}=$ aspect $/ \mathrm{mood} /$ deixis; $\mathrm{ASP}=$ aspect $\mathrm{CL}=$ noun class; $\mathrm{COMP}=\mathrm{complementizer}$; $\mathrm{DU}=$ dual; $\mathrm{EX}=$ exclusive; $\mathrm{EXT}=$ extension marker; $\mathrm{IMPV}=$ imperfective; $\mathrm{PROG}=$ progressive; ITER=iterative/durative; IN=inclusive; INST=instrumental; $\mathrm{LOC}=$ locative; $\mathrm{OM}=$ object marker; $\mathrm{PL}=$ plural; $\mathrm{PFV}=$ perfective; $\mathrm{SG}=$ singular; $\mathrm{SM}=$ subject marker.
} 
The clause vowel occurs in finite clauses and exhibits a three-way alternation marking forms with no extraction, subject extraction, and non-subject extraction, as well as other categories (see Rose et al 2013, Rose to appear for details). The extension affixes (EXT) consist of antipassive/reciprocal, causative, benefactive applicative, passive/reflexive, and locative/malfactive applicative. Object markers (OMs) are incorporated pronominals; they do not co-occur with lexical noun phrases, and they bear a close affinity to free pronouns. Relevant data for this conclusion will be presented in section 4.1 , where we outline our assumptions about the syntaxphonology interface.

As we have already seen, object markers in Moro are variably suffixes or prefixes. Setting aside phonological factors, the morphological categories which affect the position of the OM include those marking aspect and mood, spacial deixis, and clause type. For example the perfective verb forms in (6a) takes object marker suffixes, but the proximal imperfective forms in (6b) occur with object marker prefixes. ${ }^{3}$

(6)

\begin{tabular}{|c|c|c|}
\hline & a. Perfective w/objects & b. Proximal imperfective w/objects \\
\hline & g-a-tfombəð-ó & g-a-tfómbəð-a \\
\hline $1 \mathrm{SG}$ & g-a-tfombəð-ə́-jé & g-a-nə́-țombəð-a \\
\hline $2 \mathrm{SG}$ & g-a-tfombəð-ə́-yá & g-a-yá-tfombəð-a \\
\hline $3 \mathrm{SG}$ & g-a-tfombəð-ə́-nó & g-a-yó-tfombəð-a \\
\hline 1INC.DUAL & g-a-tfombəð-ə́-ńda & g-á-ńdə-tfombəð-a \\
\hline $2 \mathrm{PL}$ & g-a-tfombəð-ó-ńda & g-á-ńdə-tfombəð-a \\
\hline
\end{tabular}

${ }^{3}$ The OM shifts vowel quality depending on position. Full vowels alternate with schwa in prefix position. The vowels / i e o $\mathrm{u}$ / can reduce to schwa. We assume that the 1PL(IN.DU) alternation [nda] $\sim$ [ndə] arises from underlying /nd/ realized as [ndə] when followed by a consonant and as [nda] in word-final position. This suffix appears as [ndə] when followed by another consonantinitial suffix: $g$-a-natf-ó-ńdə-no ‘s/he gave us to him/her or s/he gave him/her to us'. 
Based on these examples alone, ${ }^{4}$ it appears as if the position of the OM should be tied to the aspectual specification of the verb.

There are two ways in which morphosyntax might condition the placement of the $\mathrm{OM}$ on the Moro verb. First, the position of the OM could be dependent on a particular morphosyntactic feature or category, such as perfective aspect. Alternately, the position of the OM might vary due to a requirement that it attach to a specific morpheme as a prefix or suffix, overriding its default specification in the other direction.

However, a close examination of the morphosyntactic categories which correlate with the two positions of the OM do not reveal generalizations along either of these lines. To see that this is the case, consider the following verbs forms which take OM suffixes:

(7) Verb forms with object marker suffixes

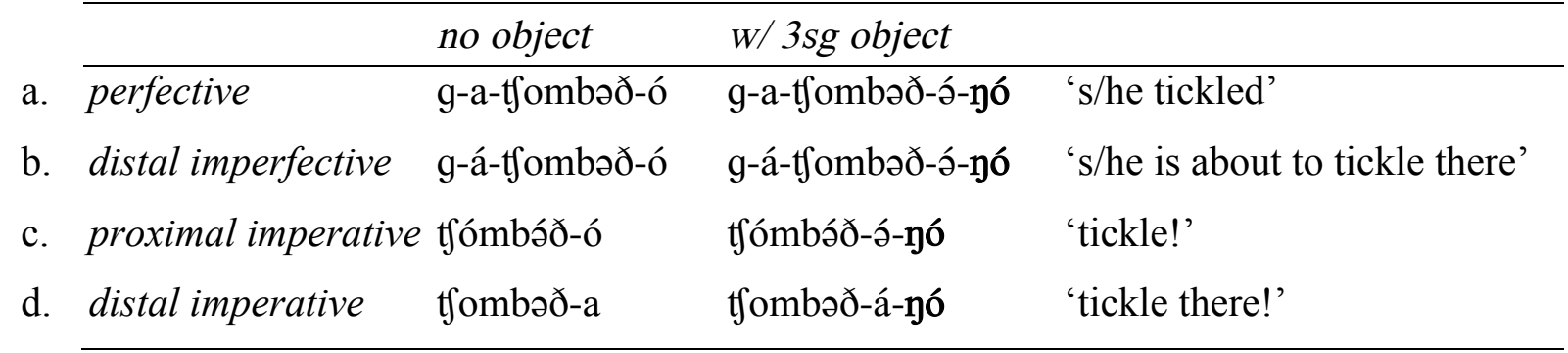

While we saw in (6) that the proximal imperfective conditions prefix OMs, the distal imperfective form in (7b) conditions suffix OMs, just like the perfective. Thus, while these two forms are both imperfective, they differ in terms of spacial deixis. Therefore, aspectual distinctions alone do not determine OM position.

Closer examination reveals that spacial deixis on verbs does not determine OM position either. ${ }^{5}$ Although proximal imperfective and distal imperfective take prefix and suffix OMs respectively,

\footnotetext{
${ }^{4}$ We consider only the markers in (8) for now. Three other OM categories will be analyzed in §5: 1IN.PL, 1EX.PL and 3PL.

${ }^{5}$ Proximal forms involve location of the event/addressee close to the speaker, whereas distal forms involve location of the event/addressee at a distance from the speaker. Distance can also be interpreted as lack of emotional involvement in the event. In addition, proximal forms may convey movement away from the speaker (also known as itive), whereas distal can be used for movement towards the speaker (also known as ventive). The main perfective does not encode
} 
both proximal and distal imperative forms $(7 \mathrm{c}, \mathrm{d})$ take OM suffixes, despite differing in their deictic specification. Likewise, consecutive verb forms take OM prefixes regardless of whether they are in the proximal or distal form, as shown in (8b-c). The following table provides the list of verb forms that cooccur with OM prefixes. The suffix of the verb forms indicates aspect/mood/deixis. The different subordinate forms (labeled 1 and 2 here) are selected by different main verbs (Rose to appear):

(8) Verb forms with object marker prefixes

\begin{tabular}{|c|c|c|c|}
\hline & no object & w/ 3 sg object & \\
\hline $\begin{array}{l}\text { proximal } \\
\text { imperfective }\end{array}$ & g-a-tfómbəð-a & g-a-yó-tfombəð-a & $\begin{array}{l}\text { 's/he is about to } \\
\text { tickle (him/her)' }\end{array}$ \\
\hline subordinate 1 prox. & (n)-án-tfómbəð-e & (n)-áy-yó-tfombəð-e & $\begin{array}{l}\text { 'that s/he tickles } \\
\text { (him/her)' }\end{array}$ \\
\hline $\begin{array}{l}\text { subordinate } 1 \text { dist./ } \\
\text { subordinate } 2 \text { prox. }\end{array}$ & (n)-áy-tfómbəð-a & (n)-án-நó-tfombəð-a & $\begin{array}{l}\text { 'that s/he tickles } \\
\text { (him/her) (there)' }\end{array}$ \\
\hline subordinate 2 dist. & (n)-áy-tfómbəð-ó & (n)-áy-Đó-tfombəð-ó & $\begin{array}{l}\text { 'that s/he tickles } \\
\text { (him/her) there' }\end{array}$ \\
\hline $\begin{array}{l}\text { consecutive prox. } \\
\text { perfective }\end{array}$ & n-ə́nว́-tfómbəð-e & n-án-yó-tfombəð-e & $\begin{array}{l}\text { 'and then s/he tickles } \\
\text { (him/her)' }\end{array}$ \\
\hline $\begin{array}{l}\text { consecutive dist. } \\
\text { perfective }\end{array}$ & n-ə́yว́-tfómbəð-a & n-ə́y-yó-tfombəð-a & $\begin{array}{l}\text { 'and then s/he tickles } \\
\text { (him/her) there' }\end{array}$ \\
\hline negative & g-an:á áy-tfómbəð-a & gan:á áy-yó-tfombəð-a & $\begin{array}{l}\text { 's/he doesn't/ didn't } \\
\text { tickle (him/her)' }\end{array}$ \\
\hline negative imperative & án:á á-tfómbəð-a & án:á á-nó-tfombəð-a & $\begin{array}{l}\text { 'don't tickle } \\
\text { (him/her)!' }\end{array}$ \\
\hline
\end{tabular}

These data also show that mood is not responsible for OM position either. Positive imperative forms take OM suffixes (7c-d), whereas negative imperatives take prefixes (8h).

direction/location distinctions, but the consecutive perfective does. Conversely, the main imperfective does encode direction/location whereas the consecutive imperfective does not. See Dimmendaal (2009) for discussion of similar distinctions in Tima, a related language. 
Most forms that take prefixes can be categorized as dependent verbs, in that they follow an auxiliary verb (in the case of the negative an:á) or are dependent on a preceding clause, as in the case of the subordinate and consecutive forms. This is reflected in an alternate subject marking paradigm particular to subordinate verbs, exemplified in (8) by the different realizations of the $3^{\text {rd }}$ singular subject marker. While 3 sg agreement is represented by a noun class concord marker in main verbs ( $k$ - in (8a)), it is realized as an invariant prefix án(á)- or áyá- in dependent verbs (8b-g). See Rose (to appear) for more details. However, the main/dependent division also does not correlate perfectly with OM position, as the proximal imperfective in (8a) is a basic main verb form. In sum, while dependent verbs all take OM prefixes, not all verbs with OM prefixes are dependent verbs, so this distinction does not provide a unified explanation.

In conclusion, no single morpho-syntactic property correlates with whether a verb form will have a prefix or suffix OM. Mood, aspect, deixis and main/dependent status all fail to explicate the patterns. Moreover, purely morphological features of the verb, the most obvious candidate being the final vowel of the verb, fail to accurately predict the position of the OM. Below we show that there are generalizations to be made across these different categories, but they do not lie in the morphosyntax of these verb forms, but rather in their tonal properties.

3. TONE PROPERTIES OF VERB STEMS AND THE POSITION OF OBJECT MARKERS. In this section, we demonstrate that the tonal characteristics of the different verb forms correlate with the position of the object markers. Moro has two basic surface tones, high (H) and low (L). Underlyingly Moro is a $\mathrm{H} / \varnothing$ tone system; L tone is not active (Jenks and Rose 2011). The tone patterns of Moro verb stems fall into two distinct groups. The first pattern is termed DEFAULT tone, due to its general predictability and dependence on the segmental and syllabic properties of verb roots. Verb forms with default tone occur with object marker prefixes. The second pattern is termed MELODIC tone, wherein the tone pattern on the stem depends solely on the particular aspect /mood/ deixis/ clause of the verb form, and ignores the segmental makeup of the verb stem. Verb forms with melodic tone occur with object marker suffixes.

3.1. Default TONE. Default tone patterns are found in the proximal imperfective and all other verb forms in (8) that co-occur with object marker prefixes. The default pattern is characterized by a high tone positioned at the left edge of the root, which extends to a second tone-bearing unit to the right, as shown in $(9 a-b)$. Jenks and Rose $(2009,2011)$ attribute this pattern to a left- 
aligned bimoraic foot which prefers $\mathrm{H}$ tone aligned to both its edges. The tone pattern depends on syllable structure in that high tone does not spread out of an initial closed or heavy syllable $(9 \mathrm{c}-\mathrm{d})$. The transcribed tone pattern (e.g. H-H or H-L) indicates the tone on the root and the tone on the following affix, typically the final aspect/mood vowel.

\begin{tabular}{lllc}
\hline Root shape & Root-suffix tone & Proximal imperfective \\
\hline a. CVCVC & HH-L & g-a-dógát-a & 'fix' \\
b. CVC & H-H & g-a-ðə́w-á & 'poke' \\
c. CVCCVC & HL-L & g-a-mª́ndəð-iə & 'ask' \\
d. CVCC & H-L & g-a-wárð-a & 'write' \\
\hline
\end{tabular}

If a root begins with a vowel, $\mathrm{H}$ tone has a different distribution. The generalization is that $\mathrm{H}$ tone avoids vowel-initial syllables unless they have a coda. Thus, the first vowel of the root is low toned if it occurs in a light syllable (10a-b). The $\mathrm{H}$ tone that appears on the second root vowel does not spread to the suffix (10a). Onsetless initial syllables do bear high tone when heavy. That $\mathrm{H}$ tone does not spread rightwards (10c-d), following the general pattern for heavy syllables exhibited in (10c-d).

\begin{tabular}{lllc}
\hline Root shape & Root-suffix tone & Proximal imperfective \\
\hline a. V.CV.C & LH-L & g-ogát-a & 'jump' \\
b V.C & L-L & g-al-a & 'slice' \\
c. VC.CV.C & HL-L & g-óndotat-a & 'dry' \\
d. VC.C & H-L & g-áff-a & 'build, shoot' \\
\hline
\end{tabular}

Note that the agreement prefix /g-/ does not license $\mathrm{H}$ on the initial root vowel. In Jenks and Rose $(2009,2011)$ it is shown that the failure of this prefix to license $\mathrm{H}$ is due to the fact this prefix and the stem occur in different tonal domains, discussed in more detail in section 3.3.

While most verb roots exhibit spreading of the $\mathrm{H}$ a single syllable to the right, there are a handful of exceptional roots that do not obey this pattern. However, the distribution of tone on these exceptional forms is systematic: they always involve a tone which does not spread e.g. $g$ - $a$-noán- $a$ 's/he is caring for' or $g$ - $a$-vádad- $a$ 's/he is sweeping.' In addition, this tone can 
appear on an onsetless initial light syllable, where $H$ tone is otherwise prohibited e.g. yáwá $\eta$-ól-a 'water is dripping'. These exceptions have $\mathrm{H}$ aligned at the left edge, as in the general pattern. There are no roots that have the shape CVCVC with a tone pattern LH or CVC with low tone. Therefore, the overarching principle of default tone distribution is $\mathrm{H}$ tone at the left edge of the root.

In conclusion, verb forms with default tone show a variety of different tone patterns depending on the syllable structure of the root (light vs. heavy syllables, C-initial or V-initial roots). There are also several verbs that have a high tone positioned at the left edge that does not extend to a second tone bearing unit regardless of syllable structure.

3.2. Melodic TONE. In contrast to default tone, 'melodic' tone refers to specific tone patterns or 'melodies' associated with particular aspect/mood/deixis categories. The verb forms with melodic tone, introduced in (7), are listed below. The distal imperfective is identical to the perfective except for the additional high-toned prefix preceding the root. ${ }^{6}$
a. perfective
$[\mathrm{L}-\mathrm{H}$
g-a-vəleð-ó
b. distal imperfective
$\mathrm{H}-[\mathrm{L}-\mathrm{H}$
g-á-vəleð-ó
c. proximal imperative
$[\mathrm{H}-\mathrm{H}$
váléð-ó
d. distal imperative
$[\mathrm{L}-\mathrm{L}$
vəleð-a

Unlike the default tone pattern, the tone patterns in (11) occur regardless of the segmental or syllabic make-up of the root, as shown below with the perfective (L-H) and proximal imperative $(\mathrm{H}-\mathrm{H})$ for a variety of different root types.

\footnotetext{
${ }^{6}$ We assume that this is a separate prefix á-rather than a high tone that appears on the clause vowel a-. This is because in subject and non-subject extraction, clauses are marked with é- and órespectively rather than a-, except in distal imperfectives. In distal imperfectives, subject and non-subject extraction are not marked overtly on the verb, but are gleaned from context. We surmise this is due to vowel hiatus of the clause prefix and the distal imperfective prefix: / $g$-é-ávəleð-ól $\rightarrow$ [kávəleðó]. Vowel hiatus in Moro is resolved in favor of the second vowel if hiatus occurs outside the derived stem.
} 


\begin{tabular}{llll}
\hline Root shape & Perfective L-H & Proximal imperative H-H & \\
\hline a. CVCVC & g-a-dogat-ó & dógát-ó & 'fix' \\
b. CVC & g-a-ðəw-ó & ðáw-ó & 'poke' \\
c. CVCCVC & g-a-mwandəð-óó & mª́ndáð-ó & 'ask' \\
d. CVCC & g-a-warð-ó & wáŕð-ó & 'write' \\
e. VCVC & g-ogət-ó & ógát-ó & 'jump' \\
f. VC & g-al-ó & ál-ó & 'slice' \\
g. VC.CVC & g-ond̄ot-ó & óndát-ó & 'dry' \\
h. VC.C & g-aff-ó & áff-ó & 'build, shoot' \\
\hline
\end{tabular}

Note that the tone of the aspect suffix is not responsible for the distinction between default and melodic tone. Both the consecutive imperfective and the perfective have a final high toned suffix

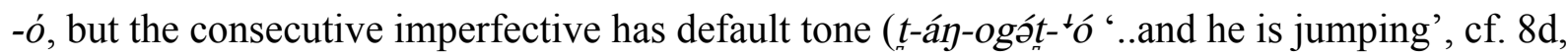
10a), whereas the perfective has melodic tone ( $g$-oget-o ' 'he jumped'). It is the tone pattern of the stem as a whole rather than the form of the individual affixes that creates the default/melodic distinction.

In summary, while default tone verb forms display a variety of tone patterns dependent on root type ${ }^{7}$ the melodic tone verb forms have a uniform tone pattern regardless of root type. The OM prefixes co-occur with default tone verb forms, whereas the OM suffixes co-occur with melodic tone forms, regardless of the morphosyntactic features that these tone patterns are associated with. Thus, the tone pattern on the verb stem precisely correlates with the position of the OM as prefix or suffix, cross-cutting various morphosyntactic categories.

3.3. DOMAINS OF TONE INTERACTION. Not only does the tone pattern of the verb stem correlate with the position of the $\mathrm{OM}$, but the tone of the OM interacts with the tone pattern of the verb stem differently according to its position. The basic pattern is as follows: when OM prefixes occur, there is no default high tone on the verb stem. On the other hand, suffixal OMs do not

\footnotetext{
${ }^{7}$ Dependent clause forms (subordinate, consecutive and negative) show different tone patterns dependent on person/number of the subject. Most forms show the standard default tone pattern, but $1 \mathrm{pl} \mathrm{excl}$ and $3 \mathrm{pl}$ are low-toned regardless of root type. These forms are discussed in $\S 6$.
} 
impact the tone pattern of the stem. ${ }^{8}$ This is illustrated with the proximal imperfective, which has default tone, and the proximal imperative, which has melodic tone:

\begin{tabular}{|c|c|c|c|c|c|}
\hline $\begin{array}{l}\text { Proximal } \\
\text { imperfective }\end{array}$ & w/ 1sg OM prefix & & $\begin{array}{l}\text { Proximal } \\
\text { imperative }\end{array}$ & w/ 1sg OM suffix & \\
\hline g-a-wóndaț-a & g-a-nə́-wəndaț-a & c. & wóndáț-ó & wóndát-ó-né & 'watch' \\
\hline g-a-vóléð-a & g-a-nó-vəleð-a & d. & váléð-ó & váléð-á-né & 'pull' \\
\hline
\end{tabular}

As shown in (13a-b), the default high tone that normally appears at the left edge of the root in the proximal imperfective disappears in the presence of the OM prefix. In contrast, the melodic high tone of the proximal imperative is unaffected by the OM suffix (13c-d).

In this section, we demonstrate that the difference in the tone behavior of the prefix versus suffix OMs can be derived from their location in different nested domains which have distinct properties in terms of $\mathrm{H}$ tone distribution and interaction. We provide evidence for these morpho-phonological domains and show how the position of the OM fits within them. The first of these is the MACROSTEM, which includes the prefix OM, progressive and iterative prefixes, verb root and extension markers, as shown in (14). The macrostem is familiar from Bantu languages and in Bantu normally includes the OM, root, extension markers and final vowel (e.g. Hyman and Ngunga 1994, Mutaka and Hyman 1990, Odden 1996, Myers 1987, 1997). In many Bantu languages, the macrostem is a domain for certain tonal processes. The main difference between Bantu and Moro is that the proposed Moro macrostem does not include the final vowel.

A second, larger domain is the INFLECTIONAL STEM, which includes the macrostem as well as the distal imperfective prefix and the aspect/mood/deixis suffixes. The macrostem is the domain of stem tone assignment, while the inflectional stem includes the affixes which determine default or melodic tone. The Moro inflectional stem is similar to the Bantu inflectional stem, but differs from it in that the Bantu inflectional stem is smaller than the macrostem and excludes the OM.

\footnotetext{
${ }^{8}$ The only exception to this pattern is the addition of a $\mathrm{H}$ tone on the vowel preceding an $\mathrm{OM}$ suffix in verbs that are all low-toned: vəleð-a $\rightarrow$ [vəleða] 'pull!' but [vəleðáné] 'pull me!' This H tone is not part of the tone melody, but appears on low-toned verbs in non-final phrase position. For example, it is found with low-toned VC verbs if an object follows: /g-a-p-a/ $\rightarrow$ [kapa] 'he carried' but [kapá gəla] 'he carried the plate'.
} 
Below we demonstrate that the INFLECTIONAL STEM consists of the verbal projections which make up the $v \mathrm{P}$ domain in syntax.

The VERB STEM consists of the inflectional stem plus a string of prefixes: complementizer, subject, class, and clause type. Thus, the VERB STEM consists of heads in the TP/CP domain in syntactic structure. Finally, at the right edge of the verb are enclitics, including the OM suffix. Syntactically, these clitics originate within the $v \mathrm{P}$ but are not incorporated into the inflectional stem. The difference in the behavior of the OM prefixes and suffixes is due to their position inside or outside of these domains. The different domains are delimited in (14):

\section{(14) Verb domains}

(COMP-SM-CLASS-CLAUSE-[AMD- \{OM/PROG-ITER-ROOT-EXT $\}$-AMD])-OM-PL-INST-LOC

( VERB STEM [I-STEM \{ MACROSTEM $\}$ I-STEM ] )

In the rest of this section we provide phonological evidence that each of these stems forms a distinct domain, and we situate the behavior of the OMs within these domains.

EVIDENCE FOR THE MACROSTEM AND INFLECTIONAL STEM. Recall from (8) that default H on the root is absent in the presence of preverbal OMs. The same patern is observed with the iterative/ durative prefix, realized by partial reduplication of the root. This prefix has the shape $\mathrm{CaC}$-, where $\mathrm{C}$ indicates a copy of the first root consonant, or Vkk- if the root is vowel-initial, where $\mathrm{V}$ copies the first vowel (15). This prefix is high-toned, and like with the prefix OM, no default $\mathrm{H}$ tone appears on the root when the reduplicant occurs.

proximal imperfective iterative proximal imperfective
a. g-a-ðów-á
g-a-ðáð-ðəw-a 'poke'
b. g-a-lág-á
g-a-lál-lag-a 'weed'
c. g-a-váléð-a
g-a-váf-fərleð-a 'pull'

\footnotetext{
${ }^{9}$ Another way of marking iterative is $/ \mathrm{r} /$ infixed as a coda of the first syllable of the root, often used with vowel-initial roots, ex. gilio ‘ 's/he is buying' vs. girlida 's/he is buying (iter.). Note
} 
d. $\quad$ g-ogát-a g-ókk-ogat-a 'jump'

When both the OM and the iterative prefix are present, the OM precedes the iterative prefix, and $\mathrm{H}$ tone appears only on the OM prefix; both the iterative prefix and the root lack $\mathrm{H}$ tone.

\begin{tabular}{|c|c|c|}
\hline proximal imperfective & \multicolumn{2}{|c|}{ 2sgOM + iterative proximal imperfective } \\
\hline g-a-ðáw-á & g-a-ná-ðað-ðəw-a & 'poke' \\
\hline g-a-vóléd-a & g-a-நá-vaf-fərleð-a & 'pull' \\
\hline
\end{tabular}

The general pattern is therefore that only the leftmost prefix bears $\mathrm{H}$ tone.

Not all high-toned prefixes trigger this effect. High-toned prefixes that occur to the left of the $\mathrm{OM}$, bolded in (17), can co-occur with default $\mathrm{H}$ tone on the root:

COMP-SM-CLASS-CLAUSE-AMD- $\{$ OM/PROG-ITER-ROOT-EXT $\}$-AMD

The boundary between the AMD and the OM represents the left edge of the macrostem. The single AMD prefix á- only occurs with melodic tone. However, to the left of this boundary are complementizers, main clause subject markers, and "clause type" prefixes indicating main clause or subject or object extraction. The $\mathrm{H}$ tones on these prefixes freely co-occur with the high tone on the root. If these prefixal $\mathrm{H}$ tones are adjacent to default $\mathrm{H}$ on the root, the $\mathrm{H}$ on the root is downstepped (marked with $\left.{ }^{\downarrow}\right){ }^{10}$

that the $/ \mathrm{r} /$ creates a heavy syllable and so default $\mathrm{H}$ tone appears on the first syllable of the root rather than the second. The verb/voleð/ preferentially uses both reduplication and /r/ infixation.

${ }^{10}$ The aspect prefix /á-/, which marks distal imperfective, requires a melodic tone pattern with no $\mathrm{H}$ on the macrostem. For this independent reason, it never cooccurs with macrostem $\mathrm{H}$ tone. It also shows no tone interaction (downstep) with preceding $\mathrm{H}$ toned prefixes: égávaleðó 'I am about to pull over there'. This suggests that this prefix is not within the macrostem. 
(18)

complementizer

subject markers:

subj extraction (clausetype): ț́-p-'⿳亠口́ff-ó

é-g-a-kwóréð-a

é-g- 'táff-a $^{11}$

g-é-k ${ }^{\mathrm{w} \downarrow}$ óréð-a '..and I am building'

'I am scratching'

'I am building'

'(she)...who is scratching'

Downstep provides evidence for two separate autosegmental H tones (Odden 1986, Myers 1997, Bickmore 2000, 2007), indicating that the $\mathrm{H}$ of the prefix is distinct from the $\mathrm{H}$ on the root, rather than a result of spreading. Independent $\mathrm{H}$ tones can also co-occur on the verb stem prefixes, and they do not trigger downstep on each other, indicating that downstep is restricted to the macrostem boundary demarcated in (17).

Just as the verb stem prefixes can co-occur with $\mathrm{H}$ tone on the root, they can also co-occur with the $\mathrm{H}$ tone of the iterative prefix or OM prefix; if adjacent, downstep is observed:
subject markers:
é-g-a-\{ðáð-ðəw-a
'I am poking (iter.)'
subj extraction (clausetype): g-é-\{ð’áð-ðəw-a '( $\mathrm{s} / \mathrm{he})$...who is poking (iter.)'
subject markers:
é-g-a- $\left\{\right.$ yá-k $k^{w} \partial r e ð-a$
'I am scratching you'

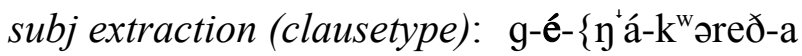
'( $\mathrm{s} / \mathrm{he})$... who is scratching you'

In summary, prefixes outside the macrostem boundary in (17) trigger downstep across the boundary on the following $\mathrm{H}$, regardless of whether the $\mathrm{H}$ is associated with the root or a macrostem-internal prefix.

We conclude, therefore, that there is tonal evidence for a morpho-prosodic constituent, the macrostem, delimited on the left by the object marker. The leftmost tone-bearing unit in this constituent bears $\mathrm{H}$ tone. This $\mathrm{H}$ tone is demarcated by downstep when another high-toned prefix is adjacent across the boundary.

There is a different kind of interaction between root $\mathrm{H}$ and suffixal $\mathrm{H}$. Here we consider the high-toned aspect/mood/deixis suffixes and the OM suffixes. Both the perfective suffix $-o$ and

\footnotetext{
${ }^{11}$ This verb form features the vowel-initial, heavy-syllabled root /-áff-/. Because of vowel hiatus between the clause-marking prefix /a-/ and the root, the clause-marking prefix is not realized, resulting in adjacency between the $\mathrm{H}$ of the subject prefix and the $\mathrm{H}$ of the root, triggering downstep.
} 
proximal imperative - $o$ co-occur with melodic tone, but while the former suffix occurs with low tone on the root (L-H pattern), the latter occurs with high tone on the root (H-H pattern). Conversely, the consecutive imperfective - $o$ co-occurs with the default tone pattern described in section 3.1 (20c-e). Downstep occurs between the root and the $-o$ suffix when these two high tones are adjacent (20c). Downstep also occurs at the macrostem left edge boundary between the the subject marker and the root (20c), the iterative prefix (20d) and the OM prefix (20e).
a. perfective
é-g-a-vəleð-ó
'I pulled'
b. proximal imperative
vóléð-ó
'pull!'
c. consecutive imperfective ígidú t-é- ${ }^{+}$váléo- ${ }^{\circ}$ ó
'I fell down and was pulling'
d. consecutive imperfective
ígidú ț-é-tdát-tavəð-ó
'I fell down and was spitting'
e. consecutive imperfective
ígidú t-é-``ná-tfombəð-ó'I fell down and was tickling you’

The existence of downstep indicates that the $\mathrm{H}$ of the root is distinct from the $\mathrm{H}$ on the prefix and suffix, rather than arising due to spreading. In contrast, downstep does not occur with the imperative (20b), suggesting an analysis of the imperative as a single autosegmental $\mathrm{H}$ spread across the stem, and not two juxtaposed $\mathrm{H}$ tones. Thus, while the perfective and the proximal imperative both involve a $\mathrm{H}$ suffix $-o$, the tone melodies of these verb forms cannot be derived directly from the presence of the form of this suffix, given that it occurs with several different patterns. In conclusion, there is tonal evidence from downstep that the AMD suffixes are outside the macrostem. Yet these AMD suffixes and the AMD prefix á- mark the aspect $/ \operatorname{mood} /$ deixis of the verb along with the type of tone that appears within the macrostem - default tone or melodic tone. Aspect/mood/deixis categories with default tone are also distinguished by the type of subject marking paradigms employed (see (8)).

Turning to OM suffixes, they show no interaction with melodic tone. There is also no downstep between the melodic $\mathrm{H}$ and the OM suffix tone, which is reminiscent of the lack of downstep between prefixal $\mathrm{H}$ tones outside of the macrostem. Recall that the reduction of /o/ to schwa is a standard phonological process in Moro.
a. é-g-a-k ${ }^{\mathrm{w}}$ əreð-ว́-yó
'I scratched him/her'
b. k'ว́réð-ว́-nó
'scratch him/her!' 
The inertness of suffixal OMs with respect to melodic tone differs markedly from the behavior of prefixal OMs, which cannot co-occur with default tone on the verb stem, and undergo downstep in the presence of a preceding prefixal tone. It is an indication that, like the AMD suffixes which precede them, the OM suffixes are not part of the macrostem.

In conclusion, internal to the macrostem, $\mathrm{H}$ tone is realized on the leftmost syllable in verbs exhibiting the default tone pattern, modulo the constraints placed on default $\mathrm{H}$ by syllable structure described in section 3.1. Evidence for the left boundary of the macrostem comes from the fact that downstep applies between adjacent $\mathrm{H}$ tones only at this boundary. Downstep also provides evidence for the right boundary, as default tone triggers downstep on the suffix $-o$ in the consecutive imperfective (20c). Outside of this domain, adjacent $\mathrm{H}$ tones co-occur and do not trigger downstep.

Turning now to the larger inflectional stem, we assume that it is the locus of default or melodic tone assignment for three reasons. First, the precise default or melodic tone patterns depend on the presence of the aspect/mood/deixis affixes. Default tone co-occurs with one of three suffixes, -e, -a, or -ó, which indicate several distinct AMD categories (see (8)). Melodic tone is accompanied by $-\mathrm{a}$ or $-\mathrm{o}$. The melodic tone pattern may be: i) no $\mathrm{H}$ tone in the macrostem (perfective and distal imperfective, marked with -ó), ii) a single autosegmental H spread across the whole inflectional stem (proximal imperative, also marked with -ó), or iii) no $\mathrm{H}$ tone at all (distal imperative, marked with -a). Second, while downstep occurs between default $\mathrm{H}$ tone and a high-toned AMD suffix in the consecutive imperfective, the same pattern is not observed between melodic tone on the root and a high-toned AMD suffix in the proximal imperative, suggesting that a single tone pattern is assigned to the whole inflectional stem. Third, melodic tone patterns conditioned by AMD affixes are confined within the inflectional stem.

EVIDENCE FOR THE VERB STEM AND ENCLITIC GROUP. Phonological evidence for the existence of the verb stem domain comes from vowel harmony. Moro exhibits vowel height harmony which raises the lower vowels /a e o/ to $[\Lambda \mathrm{i} u$ ] respectively. Every member of the inflectional stem undergoes vowel harmony as well as all prefixes attached to the inflectional stem - that is, everything within the proposed verb stem. However, suffixes to the right of the aspect/mood suffix generally do not; vowel harmony is optional on the first OM. In (22a, 22e), a verb root veð with a lower vowel /e/ is shown. The affixes attached to this root are all of the lower set /e a o/. In $(22 b, 22 f)$, a root with a high vowel $/ \mathrm{u} /$ causes the affixes to raise to their higher counterparts [i 
$\Lambda \mathrm{u}$ ]. While prefixal OMs do undergo harmony $(22 \mathrm{~g}, \mathrm{~h})$, suffixal OMs do not $(22 \mathrm{c}, \mathrm{d})$. This indicates that the prefix OMs, but not the suffix OMs, are included in the verb stem:
a. é-g-a-veð-ó 'I slapped (sthg)'
e. é-g-a-véð-á 'I am about to slap (sthg)'
b. '́-g- $\Lambda$-bug-ú 'I hit (sthg)'
f. 'i-g- $\Lambda$-búg' ${ }^{\mathrm{w}}-\hat{\Lambda} \quad$ 'I am about to hit (sthg)'
c. é-g-a-veð-á-yá 'I slapped you sg.'
g. é-g-a-yá-veð-a 'I am about to slap you sg.'
d. '́-g- $\Lambda$-bug-ó-ná 'I hit you sg.'
h. '́-g- $\Lambda-\mathfrak{n} \hat{\Lambda}-\mathrm{bug}^{\mathrm{w}}-\Lambda$ 'I am about to hit you sg.'

Note that the harmony effects cannot be attributed to direction, as aspectual final vowels do undergo harmony despite the fact that they follow the verb.

In addition to the suffixal OMs, instrumental $-j a$ and locative $-u$ clitics follow the aspect/mood/deixis suffix and likewise do not undergo or trigger vowel harmony. Thus, vowel harmony provides evidence for a constituent, the verb stem, whose right boundary follows the aspect/mood/deixis suffix. The left boundary of the verb stem is the left boundary of the verb.

The suffixes which do not undergo vowel harmony define a clitic group, which has distinct tonal effects. The plural $-\mathrm{r}$ does not bear tone. The locative and instrumental clitics do not bear $\mathrm{H}$ tone, but place a $\mathrm{H}$ tone on a preceding tone bearing unit. This can be the final aspect vowel $(23 b, c)$, or another clitic $(23 \mathrm{~d}, e)$. If both clitics occur, two $\mathrm{H}$ tones are found (23d). If two hightoned OMs occur, the second one does not bear $\mathrm{H}$ tone if it is phrase final $(23 \mathrm{f}, \mathrm{g})$.
(23) a. g-a-vádað-a]
'he is sweeping'
b. g-a-vódað-á]-ja
'he is sweeping with it'
c. g-a-vádað-á]-u
'he is sweeping in it'
d. g-a-vádað-á]-já-u
'he is sweeping with it in it'
e. $\quad g-\Lambda-d \Lambda \Gamma-\partial ́]-l o ́-j a$
'he covered them with it'
f. g-a-natf-ó]-ńdə-no
'he gave us to him/him to us (/ńdə/ + /gó/)

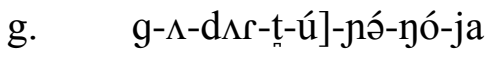
'he covered me with it for him'

The clitic group therefore requires a $\mathrm{H}$ tone at the left edge (which can appear just inside the verb stem if the clitic is low-toned) and a low tone at the phrasal right edge, presumably a $\mathrm{L} \%$ boundary tone. These two requirements compete when there is a single high-toned OM, 
however, and the $\mathrm{H}$ tone of the $\mathrm{OM}$ is maintained: $g-\Lambda-d \Lambda r-\partial ́-\eta{ }^{\prime}$ 'he covered me'. The ban on a final $\mathrm{H}$ tone is only evident if there is more than one clitic. ${ }^{12}$

The structure of the Moro verb structure ${ }^{13}$ is summarized below, with indications of the phonological processes marking each level.

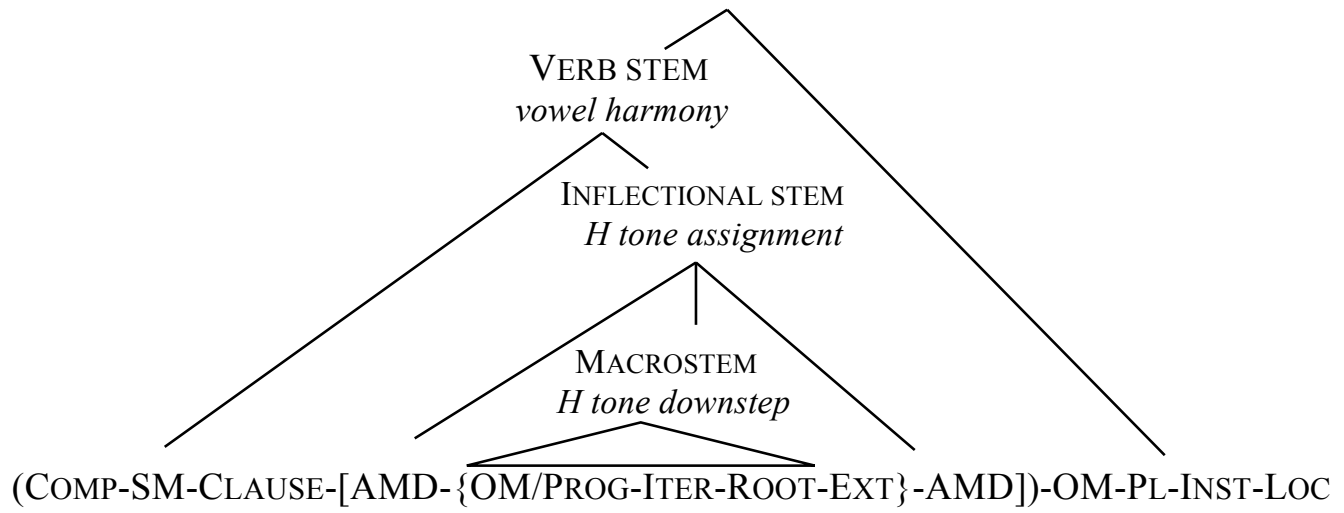

To recap, the boundaries of the MACROSTEM are marked by tonal downstep, indicating that it includes OM prefixes but not OM suffixes. Only one $\mathrm{H}$ autosegment occurs within the MACROSTEM in default tone patterns; it is this $\mathrm{H}$ which undergoes or triggers downstep across its boundaries. The INFLECTIONAL STEM is the domain for the assignment and distribution of melodic and default tone. The INFLECTIONAL STEM includes the MACROSTEM as well as the aspect/mood/deixis prefix and suffixes. The VERB STEM includes the inflectional stem and all prefixes, and is the domain of vowel harmony. Finally, OMs and other clitics are adjoined to the

12 There is evidence that the $\mathrm{H}$ tone of the final OM can be recuperated onto a preceding OM. Compare the form ganatf']-n'dr-lo 's/he gave them to us' with ganatf']-ńdr'-no 's/he gave him to us' in which the $\mathrm{H}$ tone of the $\mathrm{OM}$-nó is displaced onto the preceding low-toned $/ \mathrm{r} /$.

${ }^{13}$ In Jenks and Rose (2011), the macrostem was proposed to include the final aspect/mood vowel. However, that analysis did not consider the downstep evidence or the tonal behavior of the consecutive imperfective. There is also some evidence for the derived stem in Moro, consisting only of the root and extension suffixes. Evidence is provided from finer details of the distribution of default $\mathrm{H}$ tone in Jenks and Rose (2011). 
right edge of the VERB STEM as a clitic group, which is marked by distinct tonal properties. These enclitics do not interact with the tone on the verb stem, other than to place a $\mathrm{H}$ tone on the final low-toned syllable of the verb stem. The first OM in the clitic group optionally participates in vowel harmony.

Two main observations about the interaction between tone and object markers have been established. First, OMs occur as prefixes in verb forms exhibiting DEFAULT TONE, characterized by a left-aligned $\mathrm{H}$ tone in the macrostem, whose exact position and ability to spread in a binary fashion depends on syllable structure. Default tone occurs with a variety of different aspect $/ \mathrm{mood} /$ deixis types. The class of verb forms in which OMs occur as suffixes exhibit MELODIC TONE, a group of distinct tone patterns used to mark unique morphosyntactic categories with no sensitivity to syllable structure or the internal morphology of the macrostem. The aspect/mood/deixis category is expressed by inflectional stem affixes in addition to the default or specific melodic tone pattern. Second, the position of the OM determines how the tone of the OM interfaces with the tone of the stem. Prefixal OMs have $\mathrm{H}$ tone, while the rest of the macrostem is low-toned, failing to exhibit the characteristic default tone. When suffixal, the $\mathrm{H}$ tone of the OM does not interact with the tone pattern of the rest of the verb stem. We have seen that this behavior is unsurprising due to the location of suffixal OMs outside the verb stem, in the clitic group. We will continue to refer to the OM suffix as such for ease of exposition, although technically it is an enclitic.

In the following section, we pursue a formal analysis of the variable position of OMs in Moro as driven by the tonal properties of the verb forms with which they occur.

4. ANALYSIS OF THE DISTRIBUTION OF OBJECT MARKERS. The goal of this section is to demonstrate how the variable OM position in Moro fits into an analysis of the distribution of tone. We provide a formal Optimality Theoretic analysis of the tone interaction patterns from section 3 and derive from this analysis the two different positions of Moro OMs. Section 4.1 provides an overview of the process by which OMs are incorporated into the verb. We propose that the default position of OMs at the right edge of the stem arises in the syntax. In section 4.2, we introduce constraints and rankings to derive the tone patterns of both default and melodic tone. In section 4.3 we show how these constraints and rankings combined with the default suffix 
OM position result in the prefix OM position in default tone constructions, but the suffix OM with melodic tone.

4.1 Syntactic POSITION OF OMs. We begin by laying out our assumptions about the syntactic, morphological, and phonological status of OMs in Moro. We take OMs to be weak pronouns that occupy the complement position typical of objects, which follow the verb in Moro. OMs then combine with the verb stem for prosodic reasons. There are two pieces of evidence for this position.

First, OMs occur in complementary distrubution with full noun phrases:

a. Kúku g-a-ləvətf-ó ummiə/ gerá

CLg.Kuku CLg.SM-MAIN-hide-PFV CLg.boy/ CLy.girl

'Kuku hid the boy/girl'

b. Kúku g-a-ləvətf-ó-nó

CLg.Kuku CLg.SM-MAIN-hide-PFV-3SG.OM

'Kuku hid him/her'

OMs and nominal objects do not cooccur together in elicited forms or texts, and speakers reject forms where they co-occur. The complementarity of overt noun phrase objects and OMs demonstrates that OMs are object pronouns rather than object agreement.

Second, in contrast to subject agreement, which reflects Moro's noun class system (Gibbard et al 2009), Moro OMs show no noun class agreement, so the OM in (25b) could refer to either object in (25a) (ummia 'boy', class g-, or yerá 'girl', class $\eta$-). Like OMs, pronouns do not reflect the noun class of their referent. This provides the second piece of evidence that OMs are incorporated pronouns:

\begin{tabular}{lcllll}
\hline & Pronoun & OM & & Pronoun & OM \\
\hline 1SG & ńní & jé & 1EX.PL & j́nandá & álánda \\
2SG & ýyá & yá & 1IN.PL & ńdr & ńdr \\
3SG.HUM & ńyún & yó & 2PL & náyóndá & ńda \\
1IN.DU & (ndó)lín & ńdə/ńda & 3PL & núlwó/yúlandá lo \\
\hline
\end{tabular}


Singular nonhuman 3SG object pronouns are unmarked in Moro, and their presence is implied. In contrast, the 3PL OM -lo can refer to human or non-human plural objects.

The forms in (26) also show that while OMs are predominantly monomoraic, the free pronouns are minimally bimoraic. Compare the $2 \mathrm{SG}$ free pronoun ý.gá to the OM gá. This alternation between free and bound pronominal forms in Moro is an instance of the observation that many functional words occur in both weak (=bound) and strong (=free) forms (Zwicky 1970, Selkirk 1995). We conclude that Moro OMs are introduced into syntactic structure as prosodically deficient pronouns, forcing them to attach to the verb. We assume prosodic deficiency for both monomoraic OMs and the longer forms such as 1EX.PL-álánda, discussed further in section 5 .

Following Selkirk (1995), we interpret prosodic deficiency to mean that, as functional items, OMs do not project a phonological word in order to achieve prosodic prominence. Thus, while OMs are syntactically distinct from the verb, OMs become phonologically dependent on the verb through a process of STRAY ADJUNCTION (Anderson 2005, pp. 13, 75-85), incorporating the OM into the prosodic consituent projected by the verb. In a minimalist framework, the verb projects prosodic structure following spell-out, triggered by the phase-head $v$ (Chomsky 2000):

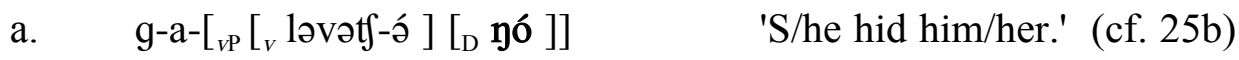

$$
\begin{aligned}
& \text { b. [ [ } \quad \text { ləvətfó ] yó ] }
\end{aligned}
$$

The inflectional stem $\left({ }_{\omega}\right)$ is the prosodic realization of the verb. Because the OM does not project its own prosodic structure, and no other prosodic structure is available in its spell-out domain, the $v \mathrm{P}$, it is stranded to the right of the inflectional stem.

In summary, OMs are structural objects of the verb, and we attribute their default position to the right of the verb to the observation that objects follow verbs in Moro. This preference below will be modeled with the constraint RIGHTMOST, which aligns clitics with the right edge of the inflectional stem (Legendre 2000). This constraint could also be formulated with reference to the right edge of the $v \mathrm{P}$, or as a faithfulness constraint requiring the $\mathrm{OM}$ to be realized in its merge position. Either way, the morphosyntactically preferred position may be overridden by phonological constraints, which push the OM to attach within the macrostem. 


\subsection{ANALYSIS OF ASPECT/MOOD/DEIXIS TONE PATTERNS}

We now present a formal analysis of the two main classes of tone distribution within the inflectional stem in Moro. A summary of the tone patterns are given below. The morphosyntactic features particular to each class are expressed constructionally, through a combination of tone, a final suffix (and in one case, a prefix), and a select subject agreement paradigm. The macrostem tone patterns and the corresponding AMD affixes are summarized here:

\begin{tabular}{|c|c|c|}
\hline tone pattern & $A M D$ affix & aspect/mood/deixis \\
\hline Melodic - No H & -ó & perfective \\
\hline Melodic - No H & á- -ó & distal imperfective \\
\hline Melodic - No H & $-\mathrm{a}$ & proximal imperative \\
\hline Melodic - All H & -ó & proximal imperative \\
\hline Default - $\mathrm{H}$ at left edge & -ó & consec. imperfective, subordinate 2 distal, \\
\hline Default - $\mathrm{H}$ at left edge & $-\mathrm{a}$ & $\begin{array}{l}\text { proximal imperfective, negative, subordinate } 2 \\
\text { proximal, subordinate } 1 \text { distal, consec.distal } \\
\text { perfective }\end{array}$ \\
\hline Default - $\mathrm{H}$ at left edge & $-\mathrm{e}$ & subordinate 1 proximal, consec. proximal perfective \\
\hline
\end{tabular}

Tone patterns assigned to particular tense-aspect-mood categories are also attested in some Bantu languages. In Makua, Yao and Kimatuumbi (Odden 1989), Makonde (Odden 1990) and Nyala (Ebarb and Marlo 2012), for example, there are no lexical tone contrasts in verb roots, but $\mathrm{H}$ tone is assigned somewhere in the verb stem in most tenses; the exact position of the $\mathrm{H}$ is morphologically conditioned by the tense/aspect. For example, Odden (1990) proposes a basic rule 'Stem H insertion' in the Chimaraba dialect of Makonde. A series of morphologically conditioned rules account for the position of the $\mathrm{H}$ tone. 'Stem Mapping $\mathrm{H}$ ' assigns $\mathrm{H}$ tone to the penultimate syllable in conditional subordinate tenses while 'Future Negative Docking' assigns $\mathrm{H}$ to the penultimate root syllable in the negative future, and 'Stem Initial H' maps $\mathrm{H}$ tone to the initial stem mora in the infinitive. Whether a rule-based or constraint-based framework is used to model the $\mathrm{H}$ tone position, some degree of morphological specificity of this kind is required.

We present a formal account of the Moro tone patterns using Optimality Theory. A rulebased framework could also be used, but we will show in section 4.3 that the OT framework is well-suited to the optimizing character of the output with respect to tone, capturing the interplay 
between the tone of the OM and the overall tone pattern of the macrostem. First, we assume that each AMD suffix in Moro is associated with a tone underlyingly: /-a/ and/-e/ are low-toned (lack a $\mathrm{H}$ autosegmental tone) and /-ó/ is high-toned. This is based on the fact that regardless of AMD construction, these affixes bear the same tone. The low-toned affixes only acquire high tone via default tone doubling with a short root. Second, roots are not specified underlyingly for tone; the tone patterns are assigned at the inflectional stem level where AMD affixes are attached. The inflectional stem contains morphemes internal to the $v \mathrm{P}$ in syntax.

We derive the distribution of the $\mathrm{H}$ tone with three faithfulness constraints and four markedness constraints.
MAX-IO(H)
Do not delete $\mathrm{H}$ tone
$\operatorname{DEP}-\mathrm{IO}(\mathrm{H})$
Do not insert $\mathrm{H}$ tone
INTEGRITY-IO(H)
*H
No input $\mathrm{H}$ can be linked to more than one output TBU
Have-H
Macrostem-H
Align(H, L; Mstem, L)
Assign one violation for every autosegmental $\mathrm{H}$ tone.
Assign one violation mark for every TBU that is not associated with a $\mathrm{H}$ tone autosegment.
Macrostem must contain $\mathrm{H}$ tone
Align left edge of $\mathrm{H}$ with left edge of MSTEM

Each AMD construction is associated with one of three rankings of these constraints. Alternate rankings for different morphological constructions are sanctioned in approaches to OT with morphological levels, such as Stratal-OT (Bermúdez-Otero 2006, forthcoming) or closely aligned Lexical Phonology \& Morphology-OT (Kiparsky 2000). However, in Stratal-OT/LPMOT, rankings are associated with general stem-level and word-level categories, whereas the forms under consideration here are all of the same general inflectional category (aspect/mood/deixis forms), and assign tone at the same morphological level. Cophonology theory, on the other hand, builds words constructionally (Inkelas 1998, Anttila 2002, 2009, Inkelas and Zoll 2005, 2007, Inkelas and Caballero to appear). Each construction is associated with semantic features and a particular ranking of phonological constraints. These constructions can be general (i.e. stem-level) or specific. Cophonology theory is therefore better suited for this kind of morphologically-specific tone assignment. 
For default tone, which has the 'H at left edge' pattern, we use the combination of two constraints, Macrostem-H and $\operatorname{Align}(\mathrm{H}, \mathrm{L}$; Mstem, L), which together require that the macrostem have a $\mathrm{H}$ tone, and that the $\mathrm{H}$ tone is positioned close to the left edge (Jenks and Rose 2009, 2011). ${ }^{14}$ These two constraints work in tandem and are distinct only to ensure the correct derivation for vowel-initial roots, where $\mathrm{H}$ tone does not appear on the first tone bearing unit. To simplify the exposition here, we combine these constraints into a single constraint: ALIGN(H,L) 'Macrostem must be aligned with a H tone at left edge'. As illustration, we use the $3 \mathrm{sg}$ consecutive perfective $t-a ́ \eta-v^{\downarrow}$ áléd- ${ }^{\downarrow} o$, which bears the complementizer prefix t-, the subject marker áy- and the AMD suffix -ó. The H tone on the macrostem triggers downstep on the suffix, and is itself downstepped by the subject marker, evidence that the $\mathrm{H}$ tone on the macrostem is a separate autosegment. $\operatorname{AL}(\mathrm{H}, \mathrm{L})$ requires $\mathrm{H}$ tone at the left edge, and the ranking of the faithfulness constraints INTEGRITY-IO(H) $\gg$ DEP-IO(H) ensures a tone is inserted rather than spread from the suffix. The linking of $\mathrm{H}$ tone on the first two vowels arises due to constraints on $\mathrm{H}$ tone extension within a foot structure that are not relevant here (see Jenks and Rose 2011). Because the root $\mathrm{H}$ tone is inserted, it does not violate INTEGRITY-IO(H). The macrostem is indicated with brackets and the inflectional stem with curly brackets. These rankings only apply to material within the inflectional stem $/ v \mathrm{P}$; this is the locus of assessment.

\begin{tabular}{|c|c|c|c|}
\hline /tt-áy-vəled-ó/ & INT-IO(H) & $\mathrm{AL}(\mathrm{H}, \mathrm{L})$ & $\mathrm{DEP}-\mathrm{IO}(\mathrm{H})$ \\
\hline a. t-áy-\{[váléð]-ó $\}$ & $* * !$ & & \\
\hline Fb. t-án- $\{[$ vóléð]-`ó $\}$ & & & $*$ \\
\hline c. t-án-\{[vəleð]-ó $\}$ & & $* !$ & \\
\hline
\end{tabular}

Candidate (30a) has a single $\mathrm{H}$ tone spread from the final suffix, violating INT-IO(H), which penalizes spreading. Candidate (30c) does not have $\mathrm{H}$ tone at the left edge of the macrostem. The winning candidate $(30 \mathrm{~b})$ satisfies $\mathrm{AL}(\mathrm{H}, \mathrm{L})$, but violates DEP-IO(H), the constraint penalizing insertion. Tones do not shift from input hosts to satisfy $\operatorname{ALIGN}(\mathrm{H}, \mathrm{L})$; the H tone on the suffix -ó

\footnotetext{
${ }^{14}$ Note that in Jenks and Rose (2011), the constraint requiring a $\mathrm{H}$ tone referenced the derived Stem rather than the larger macrostem. In this paper we have added the inflectional stem level and adjusted our analysis of the macrostem to exclude the AMD suffixes.
} 
does not move to the left edge of the macrostem. This is ruled out by high-ranking IDENT$\mathrm{IO}(\mathrm{H}) / \mathrm{OI}(\mathrm{H})$ (Jenks and Rose 2011), which we do not include in the tableaus. The same ranking of Int-IO(H), Align $(\mathrm{H}, \mathrm{L}) \gg \operatorname{DeP}-\mathrm{IO}(\mathrm{H})$ compels $\mathrm{H}$ insertion when the suffix is underlyingly low-toned, such as in the proximal imperfective form $g$-a-váléd-a.

Turning to melodic tone forms, the 'no H' pattern is found in the all low-toned distal imperative (ex. valeð-a), the perfective (ex. g-a-valeð-ó), and distal imperfective (ex. $g$-á-vale $o$ ). The constraint $* \mathrm{H}$, which penalizes each autosegmental $\mathrm{H}$ tone, is ranked high in these forms. The ranking of MAX-IO(H) $\gg * \mathrm{H}$, INT-IO(H) prevents deletion of affixal $\mathrm{H}$ tones where relevant. This is illustrated with the perfective in (31).

(31) Perfective: $\quad$ MAX-IO(H) $\gg *$ *H, Int-IO(H); DeP-IO(H)

\begin{tabular}{|r||c|c|c|c|}
\hline /g-a-valeð-ó/ & MAX-IO(H) & $* \mathrm{H}$ & $\mathrm{INT}-\mathrm{IO}(\mathrm{H})$ & DEP-IO(H) \\
\hline a. g-a- $\{[$ vəleð]-o\} & $* !$ & & & \\
\hline o. g-a-\{[vəleð]-ó\} & & $*$ & & \\
\hline c. g-a-\{[vóléð]-ó\} & & $*$ & $* * !$ & \\
\hline d. g-a-\{[váléð]-'ó\} & & $* * !$ & & $*$ \\
\hline
\end{tabular}

Candidate (31a) has no $\mathrm{H}$ tone, but $\mathrm{MAX}-\mathrm{IO}(\mathrm{H}) \gg{ }^{*} \mathrm{H}$ favors preserving the $\mathrm{H}$ tone on the suffix. Candidate (31c) spreads tone from the suffix to the left edge of the macrostem, violating INT-IO(H). Candidate (31d) inserts a tone, violating DEP-IO(H) (which is not crucially ranked), but also incurring an extra ${ }^{*} \mathrm{H}$ violation. Candidate (31b) is therefore the winner. This constraint ranking will also produce the same tone patterns on forms with the iterative prefix on the macrostem. We assume that since this ranking is associated with the inflectional stem, it is at that level that the form is being assessed; therefore ${ }^{*} \mathrm{H}$ violations outside the inflectional stem would not be counted.

To summarize, in the 'no $\mathrm{H}$ pattern', $\mathrm{AL}(\mathrm{H}, \mathrm{L})$ must be ranked below * $\mathrm{H}$ since no $\mathrm{H}$ tone occurs at the left edge of the macrostem. Conversely, in the default tone cases, * $\mathrm{H}$ would be ranked below $\operatorname{AL}(\mathrm{H}, \mathrm{L})$. The rankings are given below:

$$
\begin{aligned}
& \mathrm{H} \text { tone at left edge } \quad \mathrm{MAX}-\mathrm{IO}(\mathrm{H}), \mathrm{InT}(\mathrm{H})-\mathrm{IO}, \mathrm{AL}(\mathrm{H}, \mathrm{L}) \gg \mathrm{DEP}-\mathrm{IO}(\mathrm{H}),{ }^{*} \mathrm{H} \\
& \text { no } \mathrm{H} \text { tone } \\
& \operatorname{MAX}-\mathrm{IO}(\mathrm{H}) \gg * \mathrm{H}, \mathrm{INT}-\mathrm{IO}(\mathrm{H}) \gg \mathrm{AL}(\mathrm{H}, \mathrm{L}) ; \operatorname{Dep}-\mathrm{IO}(\mathrm{H})
\end{aligned}
$$


Turning to the 'all $\mathrm{H}$ tone' melodic pattern, the proximal imperative (ex. váléð-ó), we assume that $\mathrm{H}$ tone is spread from the suffix - $\mathrm{o}$ to the left edge of the stem to every TBU. This is accomplished with HAVE-H (McCarthy et al 2012), which requires every TBU to bear $\mathrm{H}$ tone. ${ }^{15}$ Assuming that the suffix-ó has an underlying $\mathrm{H}$ tone, the constraint INT-IO(H), responsible for preventing spreading, is ranked below HAVE-H. DEP-IO(H), which penalizes H insertion, is ranked above INT-IO $(\mathrm{H})$, resulting in a preference for spreading, as in candidate (32b). We do not show MAX-IO(H) here but assume that it maintains its high ranking.

\begin{tabular}{|c|c|c|c|c|}
\hline /vəleð-ó/ & $\begin{array}{c}\text { DEP-IO } \\
(\mathrm{H})\end{array}$ & HAVE-H & $\begin{array}{l}\text { INT- } \\
\mathrm{IO}(\mathrm{H})\end{array}$ & ${ }^{*} \mathrm{H}$ \\
\hline$\sigma$ a. $\{[$ váléð]-ó $\}$ & & & ** & * \\
\hline b. $\{[$ váléð]-乩\} & $* !$ & & & $* *$ \\
\hline c. $\{[$ vale $ð]-o ́\}$ & & $* * !$ & & * \\
\hline
\end{tabular}

* $\mathrm{H}$ is ranked below HAVE- $\mathrm{H}$. The reverse ranking produces the melodic 'no $\mathrm{H}$ tone' forms. The other markedness constraint, $\mathrm{AL}(\mathrm{H}, \mathrm{L})$ does not directly conflict with HAVE-H, since they both place $\mathrm{H}$ tone at the left edge. HAVE-H conflicts with other aspects of default tone constraint ranking that restricts $\mathrm{H}$ tone to the foot at the left edge; we do not consider these here.

In conclusion, each AMD construction is associated with a different ranking:

$$
\begin{aligned}
& \text { Default }- \text { H tone at left edge } \\
& \qquad \text { MAX-IO(H), Int }(\mathrm{H})-\mathrm{IO}, \mathrm{AL}(\mathrm{H}, \mathrm{L}) \gg \operatorname{DEP}-\mathrm{IO}(\mathrm{H}),{ }^{*} \mathrm{H} ; \mathrm{HAVE}-\mathrm{H}
\end{aligned}
$$

${ }^{15}$ Another possibility is to use the $\mathrm{AL}(\mathrm{H}, \mathrm{L})$ constraint already employed for default tone. Constraint ranking of faithfulness constraints would favor spreading (assigning tone to every TBU between the left edge of the stem and the suffix) over the insertion found in default tone. However, the proximal imperative differs from the default tone cases in ignoring syllable structure, so if this latter approach were taken, alternate rankings of constraints preventing spreading beyond a foot or avoidance of $\mathrm{H}$ tone on the first vowel of a vowel-initial root would also be required. We therefore opt for the more encompassing HAVE-H constraint. 


\author{
Melodic - no H tone \\ MAX-IO(H) $\gg *$ H, INT-IO(H) $\gg$ AL(H,L), HAVE-H; DeP-IO(H) \\ Melodic - all H tone \\ MaX-IO(H), Dep-IO(H), Have-H $\gg \mathrm{Int}-\mathrm{IO}(\mathrm{H}),{ }^{*} \mathrm{H} ; \mathrm{AL}(\mathrm{H}, \mathrm{L})$
}

Equivalent characterizations of these constructions can also be formulated in a rule-based framework. The all- $\mathrm{H}$ toned forms would be generated by a rule spreading $\mathrm{H}$ leftwards, and the default $\mathrm{H}$-stem would be generated by a rule inserting $\mathrm{H}$ tone and positioning it at the left edge of the macrostem. No rule of $\mathrm{H}$ insertion or spreading is required for the low toned forms. However, as we shall demonstrate, when these constraint rankings interact with a constraint requiring the $\mathrm{OM}$ to be situated at the right edge of the verb stem, the position of the $\mathrm{OM}$ as either a prefix or suffix follows from tone realization constraints.

\title{
4.3. ANALYSIS OF OM POSITION
}

We equated the inflectional stem with the $v \mathrm{P}$ in syntactic structure, a constituent which includes the verb, aspect and the object. We argued in section 4.1 that OMs can be incorporated into the macrostem as prefixes or internal clitics, but are otherwise excluded from the prosodic constituent projected by the verb and cliticized at the right edge of the inflectional stem or the verb stem (there is no distinction at the right edge), forming their own prosodic domain outside of the inflectional stem. To make this more explicit, we adopt the following constraint:

$$
\begin{aligned}
& \text { RightMost(CL,L;INFLSTEM,R) Align the left edge of a clitic with the right edge } \\
& \text { of the inflectional stem. }
\end{aligned}
$$

What causes the OMs to be prosodically incorporated as prefixes/internal clitics? First, OMs are not lexically specified for prefix or suffix status; their position in the verb is derived from their prosodic incorporation - either as an enclitic or as an internal clitic based on tone requirements of the stem. Second, prefixal OMs satisfy the phonological constraints of default tone, as the $\mathrm{H}$ tone they bear can be realized in the initial position of the macrostem. The claim that OMs bear $\mathrm{H}$ tone underlyingly is based on three arguments: i) alternating OMs appear with a $\mathrm{H}$ tone when they are suffixes; ii) their corresponding free pronouns also have $\mathrm{H}$ tone, and iii) not all OMs have $\mathrm{H}$ tone, so there must be a lexical distinction between these two groups. OMs are uniquely 
mobile within the Moro verb. We assume that the other high-toned affixes are lexically specified for position, whereas the other verbal clitics (3PLOM, INSTRUMENTAL, LOCATIVE) are low-toned, and cannot be displaced (see $\S 5$ for an analysis).

The $\mathrm{H}$ tone of the OM satisfies the $\mathrm{AL}(\mathrm{H}, \mathrm{L})$ constraint as a prefix without violating DEP$\mathrm{IO}(\mathrm{H})$, the constraint against inserting a $\mathrm{H}$ tone. If the $\mathrm{OM}$ were realized as an enclitic, then a $\mathrm{H}$ tone would need to be inserted on the stem. Taking the ranking proposed for default tone, we slot Rightmost in below DeP-IO(H). We leave out the constraints MAX-IO(H) and HAVE-H for reasons of space; they are not pertinent to these forms.

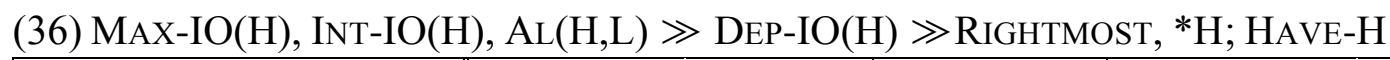

\begin{tabular}{|r||c|c|c|c|c|}
\hline \multicolumn{1}{|c|}{ /g-a-vəleð-a né/ } & INT-IO(H) & AL(H)-L & DEP-IO(H) & RiGHTMOST & $* \mathrm{H}$ \\
\hline \hline o a. g-a- $\{[$ nó-vəleð]-a\} & & & & $*$ & $*$ \\
\hline b. g-a- $\{[$ vóléð]-a\}-né & & & $* !$ & & $*$ \\
\hline c. g-a-\{[vəleð]-a\}-né & & $* !$ & & & \\
\hline d. g-a-\{[vóléð]-á\}-né & $* * * !$ & & & & $*$ \\
\hline
\end{tabular}

This ranking favors a prefix/internal clitic over a suffix/ enclitic due to the avoidance of a DEP$\mathrm{IO}(\mathrm{H})$ violation, which default tone forms normally incur. While $\mathrm{H}$ tone itself cannot be displaced from one segment to another, the clitic bearing the $\mathrm{H}$ tone can be realized in different positions.

In the melodic verb forms, a prefix realization of the OM is not optimal. Consider first the 'no $\mathrm{H}$ tone' forms. *H and $\mathrm{INT}-\mathrm{IO}(\mathrm{H})$ conspire to prevent additional $\mathrm{H}$ tones on the inflectional stem. Positioning a high-toned $\mathrm{OM}$ at the left edge of the macrostem increases $* \mathrm{H}$ violations as well as violating Rightmost (37c). Deleting the H tone from a prefix OM (37a) is prevented by $\operatorname{MAX}-\mathrm{IO}(\mathrm{H}) \gg * \mathrm{H}$, previously motivated to account for the basic forms. The candidate with the suffix OM (37b) is therefore preferred. We have positioned RIGHTMOST on a par with *H, but if ${ }^{*} \mathrm{H}$ is the determining constraint, the ranking of RIGHTMOST is not crucial. 
(37) MaX-IO(H) 》Int-IO(H), *H, Rightmost $\gg$ Have-H, Al(H,L); Dep-IO(H)

\begin{tabular}{|c|c|c|c|c|c|c|c|}
\hline /g-a-valeð-ó né/ & $\begin{array}{l}\text { MAX- } \\
\mathrm{IO}(\mathrm{H})\end{array}$ & $\begin{array}{l}\text { INT- } \\
\mathrm{IO}(\mathrm{H})\end{array}$ & ${ }^{*} \mathrm{H}$ & $\begin{array}{l}\text { RIGHT } \\
\text { MOST }\end{array}$ & $\begin{array}{c}\text { HaVE- } \\
\text { H }\end{array}$ & $\begin{array}{c}\mathrm{AL}(\mathrm{H}, \\
\mathrm{L})\end{array}$ & $\begin{array}{l}\text { DEP- } \\
\mathrm{IO}(\mathrm{H})\end{array}$ \\
\hline a. g-a-\{[nə-vəleð]-ó $\}$ & $* !$ & & * & * & $* * *$ & $*$ & \\
\hline$\sigma$ b. g-a-\{[vəleð]-á\}-né & & & * & & ** & * & \\
\hline c. g-a-\{[nว́-vəleð]-ó\} & & & $* * !$ & $*(!)$ & ** & & \\
\hline
\end{tabular}

For the 'all $\mathrm{H}$ tone' melodic form, the proximal imperative, HAVE-H ensures that every TBU has a $\mathrm{H}$ tone, so (38a) is ruled out. The choice comes down to candidates (38b) and (38c). Both candidates satisfy HAVE-H equally. However, incorporation of the OM into the macrostem in (38b) incurs a RIGHTMOST violation, so cliticization outside the inflectional stem is preferred. The ranking of RightMOST is not crucial, but it determines the winning candidate. Thus, the suffixal position of the OM in these forms follows from RiGHTMOST as there are no tonal preference constraints favoring other options. Subscripts refer to tone autosegments.

\begin{tabular}{|c|c|c|c|c|c|}
\hline /voleð-ó 2 né $1 /$ & MAX-IO(H) & DEP-IO(H) & HAVE-H & INT-IO(H) & RightMOST \\
\hline a. $\left\{\left[\right.\right.$ nó 1 -vəleð]-óo $\left.{ }_{2}\right\}$ & & & $* *$ ! & & $*$ \\
\hline 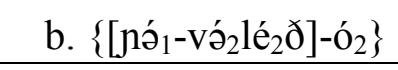 & & & & $* *$ & $* !$ \\
\hline$\sigma$ c. $\left\{\left[\right.\right.$ vó $\left.\left._{2} e_{2} e_{2} \partial-\partial_{2}\right]\right\}$-né & & & & $* *$ & \\
\hline 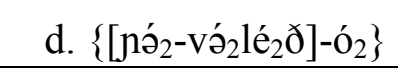 & $* !$ & & & $* * *$ & $*$ \\
\hline
\end{tabular}

To summarize, the high tone of the OM satisfies the default tone pattern of a $\mathrm{H}$ tone at the left edge of the macrostem, thereby sanctioning its realization as a prefix. As long as RIGHTMOST is ranked below DEP-IO in default tone forms, high-toned OM prefixes are optimal. In contrast, there is no benefit to the OM appearing as a prefix in the melodic tone forms. The constraint rankings motivated in section 4.2 rules out a prefixal OM; the position of RIGHTMOST is not crucial, but it does favor a suffix OM. In these cases the OM is realized as an adjoined clitic outside the inflectional stem. We conclude that the realization of the $\mathrm{OM}$ as an incorporated prefix is phonologically determined by the tone properties of the OM in combination with the tone requirements of the stem to which it attaches. 
This analysis makes two further predictions. First, if an OM is low-toned, it should surface as a suffix even with verb forms exhibiting default tone, because it cannot provide a $\mathrm{H}$ tone for the macrostem. Second, if there are two OMs, only one should appear as a prefix, since only one $\mathrm{OM}$ is needed to satisfy the macrostem $\mathrm{H}$ tone requirement. The following section demonstrates that both of these predictions are true.

5. MoRe EVIDENCE FOR THE ROLE OF TONE: Non-MObiLe OMs. The OMs we have examined so far all alternate between prefix and suffix depending on default or melodic tone, and they are all high-toned. However, some OMs do not alternate at all, and when there are two OMs, only one can appear as a prefix; the other appears in the enclitic position.

There are three cases of non-alternation that we consider in this section. The first nonalternating $\mathrm{OM}$ is exceptional because of its tone. As pointed out in the introduction in example (3), the 3 pl marker -lo is low-toned, and consistently appears as a suffix. ${ }^{16}$ In addition, the two $1 \mathrm{pl}$ forms in the OM paradigm show split behavior. They are exclusively suffixes in verb forms with melodic tone, but are split between a prefix and a suffix in verb forms with default tone:

\begin{tabular}{lll}
\hline & Perfective (suffix OM) & Proximal imperfective (prefix OM) \\
\hline 1EX.PL & g-a-vəleð-á-lánda & g-a-jó-vəleð-a-lánda \\
1IN.PL & g-a-vəleð-ó-ńd-r & g-á-ńdə-vəleð-a-r \\
3PL & g-a-vəleð-ó-lo & g-a-vóléð-a-lo \\
\hline
\end{tabular}

While the 1PL forms bear $\mathrm{H}$ tone, they possess properties distinct from other OMs. In the case of the 1 st exclusive plural OM, it is a disyllabic affix ${ }^{17}$, and in the case of the 1 st inclusive plural

${ }^{16}$ This is true for the speakers we have worked with on Thetogovela Moro. The dialect of Moro reported in Black and Black (1971) has prefixal 3PL OM. However, as Black and Black do not mark tone (and in fact, state incorrectly, that Moro is not a tone language), it is not clear if the difference in the position of the 3PL OM correlates with a difference in tone, or whether that dialect does not determine OM position through constraints on tone.

${ }^{17}$ In Jenks \& Rose (2011), this prefix was assumed to be-álánda. Discussions with Angelo Naser, a Thetogovela Moro speaker and member of the Moro Language Committee in Sudan, prompted 
$\mathrm{OM}$, it is actually polymorphemic, with the second morpheme low-toned. This section demonstrates that the tonal analysis of mobile OMs presented in the previous section not only can accommodate these patterns, but in fact predicts the patterns of these OMs. We take this result to be a strong argument for the analysis of OM mobility based on the distribution of tone within the verb.

5.1. Non-Alternating 3PL. Unlike all the other OMs, the 3PL does not bear H tone. It is also the only OM not to show variable positioning. Our analysis predicts this pattern. The low-toned $\mathrm{OM}$ is not specified with a $\mathrm{H}$ tone that can satisfy $\operatorname{AL}(\mathrm{H}, \mathrm{L})$ for default tone cases, and it would incur a phonological faithfulness violation of $\operatorname{DEP}-\mathrm{IO}(\mathrm{H})$ if it were realized as a prefix, since a $\mathrm{H}$ tone would be inserted on it. In addition, realization as a prefix incurs a violation of RIGHTMOST. This is illustrated in (40) for the proximal imperfective verb form:

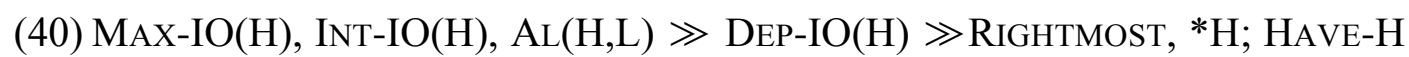

\begin{tabular}{|c||c|c|c|c|c|}
\hline /g-a-vəleð-a lo/ & INT-IO(H) & AL(H,L) & DeP-IO(H) & Rightmost & $* \mathrm{H}$ \\
\hline \hline a. g-a- $\{[$ ló-vəleð]-a $\}$ & & & $*$ & $* !$ & $*$ \\
\hline b. g-a- $\{[$ vóléð]-a\}-lo & & & $*$ & & $*$ \\
\hline c. g-a- $\{[$ lo-vóléð]-a $\}$ & & $* !$ & $*$ & $*$ & $*$ \\
\hline
\end{tabular}

There is no phonological benefit to -lo being realized as a prefix, so it is realized as an enclitic.

As for melodic tone, it might appear that the 3PL low-toned OM-lo could appear as a prefix, since it does not introduce $\mathrm{H}$ tone into the macrostem, which is a requirement of the 'no $\mathrm{H}$ tone' melodic tone forms. But, there is no benefit to the prefixal position of this OM; it violates RIGHTMOST and also does not bear $\mathrm{H}$ tone to satisfy lower-ranked constraints.

a reanalysis as -lánda. The [a] is analyzed as the AMD suffix of the previous stem. When the stem ends in -ó, it harmonizes with the following vowel and becomes [á]. See also Rose (to appear). 
(41) MAX-IO(H) $\gg$ Int-IO(H), ${ }^{*}$ H, Rightmost $\gg$ HAVE-H, AL(H,L); DeP-IO(H)

\begin{tabular}{|c|c|c|c|c|c|c|}
\hline /g-a-vəleð-ó/ & $\begin{array}{l}\text { MAX- } \\
\mathrm{IO}(\mathrm{H})\end{array}$ & $\begin{array}{l}\text { INT- } \\
\mathrm{IO}(\mathrm{H})\end{array}$ & $* \mathrm{H}$ & $\begin{array}{r}\text { RIGHT } \\
\text { MOST }\end{array}$ & $\begin{array}{c}\text { HAVE- } \\
\mathrm{H}\end{array}$ & $\operatorname{AL}(\mathrm{H}, \mathrm{L})$ \\
\hline a. g-a- $\{[$ lo-vəleð]-ó $\}$ & & & * & $* !$ & $* * *$ & $*$ \\
\hline$\sigma$ b. g-a-\{[vəleð]-ə́ $\}-10$ & & & * & & ** & $*$ \\
\hline c. g-a-\{[ló-vəleð]-ó $\}$ & & & $* * !$ & * & $* *$ & \\
\hline d. g-a-\{[ló-vóléð]-ó $\}$ & & $* * * !$ & $*$ & & & \\
\hline
\end{tabular}

It is also clear that the 3PL - lo stands no chance of appearing as a prefix in the all H-toned proximal imperative form. It would either acquire $\mathrm{H}$ tone or fail to realize $\mathrm{H}$ tone in the inflectional stem, either way violating a higher-ranked constraint as well as RIGHTMOST:

(42) MaX-IO(H), DeP-IO(H), Have-H 》Int-IO(H), Rightmost, *H; Al(H,L)

\begin{tabular}{|c|c|c|c|c|c|}
\hline /valeð-ó ${ }_{2} \quad l_{1} /$ & $\begin{array}{l}\text { MAX- } \\
\mathrm{IO}(\mathrm{H})\end{array}$ & $\begin{array}{l}\text { DEP- } \\
\mathrm{IO}(\mathrm{H})\end{array}$ & $\begin{array}{c}\text { HAVE- } \\
\text { H }\end{array}$ & $\begin{array}{l}\text { INT- } \\
\mathrm{IO}(\mathrm{H})\end{array}$ & $\begin{array}{l}\text { RIGHT } \\
\text { MOST }\end{array}$ \\
\hline a. $\{[1$ lo-vəleð]-ó $\}$ & & & $* * * !$ & & $*$ \\
\hline 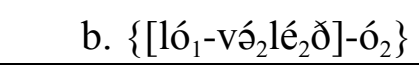 & & $* !$ & & $* *$ & $*$ \\
\hline c. $\left\{\left[\right.\right.$ vá $\left.\left._{2} l e_{2} \partial-a_{2}\right]\right\}-\mathrm{lo}_{1}$ & & & & $* *$ & \\
\hline d. $\left\{\left[\right.\right.$ ló $_{2}$-vó 2 lé 2 ð] $\left.]-o_{2}\right\}$ & & & & $* * * !$ & $*$ \\
\hline
\end{tabular}

Although -lo does differ from other OMs in that it can refer to objects and animals as well as humans, it is hard to see how this property prevents its realization as a prefix. Requiring that prefix OMs be specified as [+human], but suffix OMs do not seems like an ad hoc stipulation. In contrast, the phonological analysis connects the behavior of -lo directly to its tone specification, the same factor driving prefix/suffix status.

5.2. SPLit OMs. Turning now to the 1PL OMs, the 1IN.PL, ńdr, is split in two in the prefixinducing verb forms. There is evidence that ńdr is actually composed of two affixes. The suffix $-r$ appears in other verb forms in Moro to mark plurality, and never appears as a prefix. It can be added to $1 \mathrm{DU}$ to create $1 \mathrm{PL}$ (42b), and to imperative singulars to create imperative plurals (42d): 


$$
\begin{array}{lll}
\text { a. } & \text { áló-g-a-vóléð-a } & \text { 'we (IN.DU) are pulling’ } \\
\text { b. } & \text { áló-g-a-vóléð-a-r } & \text { 'we (IN.PL) are pulling' } \\
\text { c. } & \text { vóléð-ó } & \text { 'pull (SG.)! } \\
\text { d. } & \text { vóléð-ó-r } & \text { 'pull (PL.)! }
\end{array}
$$

Therefore, it is highly plausible that 1PL is marked by ńd, the same marker found in 1dual, and a plural marker $-r$, in a similar fashion to the way subjects are marked in (42). The ńd appears with epenthetic [ə] when a prefix, but with a final [a] when a suffix, as schwa cannot appear word-finally. The fact that only one marker is prefixed follows from the analysis developed so far. There is no benefit to having $-r$ in the macrostem as it is not high-toned, and the ${ }^{\prime} d$ satisfies the macrostem $\mathrm{H}$ requirement.

Now consider the affix -lánda, which is consistently a suffix. When it occurs in a default tone verb form, an extra nó- prefix appears. This prefix is the same as the 1SG OM prefix. Given this similarity, we interpret the nó- as a general $1^{\text {st }}$ person prefix, rather than $1^{\text {st }}$ singular. With default tone verb forms, it appears in the prefix position and -lánda is used in addition to differentiate it from 1SG. The use of both are unnecessary with melodic tone forms, and only -lánda appears. Most prefixes in Moro are monomoraic (C-, V-, CV-) or maximally bimoraic (CVC-, VCV-). A trimoraic prefix of this size (-CVCCV) is otherwise unattested. We assume that, -lánda is too long to meet the prosodic criterion to be a prefix. Instead, another H-tone bearing monomoraic prefix is co-opted to appear in the prefix position instead.

This completes the analysis of the object markers marking all eight person/number combinations in Moro. In the following section, we turn to verbs with two OMs. We demonstrate how the analysis so far developed naturally extends to these cases, too.

5.3. DOUbLE OBJECT MARKERS. In Moro, ditransitive verbs can occur with two OMs, including those which are ditransitive due to applicativization or causativization. These double object constructions show two relevant properties: 1) only one OM at a time may occur in prefix position and 2) OMs are linearly ordered by person/number. The first property follows from the phonological analysis so far developed. The second property is independent of that analysis, and follows from reference to the person hierarchy as an ordering effect. 
With melodic tone forms, double OMs both appear on the verb in the suffix position. For double $\mathrm{OMs}$, the order is $1 \mathrm{SG}>\{2 \mathrm{SG} \sim 1 \mathrm{DU} / \mathrm{PL}\}>3 \mathrm{SG}>3 \mathrm{PL}$. This requirement overrides any ordering with respect to semantic role, resulting in ambiguity:

$$
\begin{aligned}
& \text { a. 1SG }>\text { 3SG 9-a-natf-ó-nó-no } \\
& \text { SM.CL-MAIN-give-PFV-1SGOM-3SGOM } \\
& \text { 's/he gave me to her/him' or 's/he gave her/him to me' } \\
& \text { b. } \quad 1 \mathrm{SG}>2 \mathrm{SG} \text { g-a-natf-á-nó-ná-no } \\
& \text { SM.CL-MAIN-give-PFV-1 SGOM-2SGOM-no }{ }^{18} \\
& \text { 's/he gave me to you' or 's/he gave you to me' }
\end{aligned}
$$

The order $1>2>3$ follows the Person Hierarchy (Silverstein 1976), where 1,2 $>3$. The Person Hierarchy is active in a variety of languages and phenomena. Clitic order in Romance (Perlmutter 1971, Bonet 1995, Heap 2005, Nevins 2007) and Arabic (Fassi Fehri 1993:104) rely on the Person Hierarchy, although for these languages, clitic order interacts with the person-case constraint. African languages such as Kera (Ebert 1979), Shambala (Duranti 1979) and Haya (Hyman and Duranti 1982) show evidence for ordering between 1st and 3rd OMs, where the 1st person marker is closer to the verb stem, but the ordering is also connected to semantic role.

In default tone stems, the order of object markers is also determined by the person hierarchy, but only one prefix is allowed, the one highest on the person hierarchy. The other object marker appears as a suffix following the same linear order. Compare the melodic tone sequences in $(45 \mathrm{a}, \mathrm{b})$, with those with default tone in $(45 \mathrm{c}, \mathrm{d})$ :

\footnotetext{
${ }^{18}$ The suffix - $\eta \dot{ }$ appears in some constructions with 2SG or 2PL. This suffix has the form of the 3sg object marker, but it does not contribute any 3SG meaning. Recall that the OM in word-final position loses $\mathrm{H}$ tone after a preceding $\mathrm{H}$-toned $\mathrm{OM}$.
} 


\section{Perfective}

a. g-a-natf-á-nó-no

CL.SM-RTC-give-PFV-1SGOM-3SGOM

's/he gave me to her/him'

's/he gave her/him to me'

b. g-a-natf-ó-ńd-r-no

CL.SM-RTC-give-PFV-1IN.PL-PL-3SGOM CL.SM-RTC-1IN.PL-give-IMPV-1IN.PL-PL-3SGOM

's/he gave us all to her/him'

's/he gave her/him to us all'
Proximal imperfective

c. g-a-nó-natf-a-nó

CL.SM-RTC-1 SGOM-give-IMPV-3SGOM

's/he is about to give me to her/him'

's/he is about to give her/him'

d. g-a-ńdə-natf-a-ŕ-no

The fact that only one object marker appears as a prefix follows from the analysis already developed. Only one high-toned $\mathrm{OM}$ is needed to satisfy $\mathrm{Al}(\mathrm{H}, \mathrm{L})$. Fronting two would violate RIGHTMOST unnecessarily.

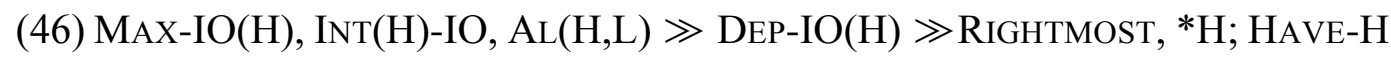

\begin{tabular}{|c|c|c|c|c|c|}
\hline /g-a-natf-a ર́ yó/ & MAX-IO-H & $\begin{array}{l}\text { INT- } \\
\mathrm{IO}(\mathrm{H})\end{array}$ & $\mathrm{AL}(\mathrm{H}, \mathrm{L})$ & DEP-IO(H) & $\begin{array}{l}\text { RIGHT } \\
\text { MOST }\end{array}$ \\
\hline$\checkmark$ a. g-a-[\{nó-nat $\}$-a]-ıó & & & & & * \\
\hline b. g-a-[\{nź-yó-natf\}-a] & & & & & $* * !$ \\
\hline c. g-a-[\{nó-no-natf\}-a] & $* !$ & & & & ** \\
\hline d. g-a-[\{nátf\}-a]-ná-yó & & & & $* !$ & \\
\hline
\end{tabular}

It is also predicted that two 3pl-lo markers should always appear as suffixes. In fact, for reasons not understood, two 3pl markers are disallowed in any configuration. Only one can appear, and the other must be left unexpressed.

The Person Hierarchy constrains the linear order of OMs regardless of whether the first is prefixal or suffixal: those OMs that are higher on the person hierarchy must occur closer to the verb stem. Given the structure of the Moro verb, the prefixal OM position is hierarchically closer to the verb than an OM enclitic. We do not develop an analysis of how the person hierarchy is incorporated formally here. Various proposals have been offered in the literature, ranging from alignment constraints (Curnow 1999) to particular feature geometry effects on person/number 
feature combinations (Harley and Ritter 2002, Heap 2005, Nevins 2007). These accounts provide formal methods of describing the restriction, but our goal here is simply to show that the phonological account predicts a single OM prefix with double object constructions.

In conclusion, double object constructions introduce ordering of OMs based on the person hierarchy. Independently of this restriction, only one prefix is allowed in default tone constructions. While this could be due to a templatic position that allows only a single affix, we show how it follows from the tone-based analysis. Only a single H toned OM is needed to satisfy the prosodic default tone requirement; an additional OM incurs further constraint violations.

6. TONE DISTRIBUTION DETERMINED BY VERB STEM. So far we have only analyzed tone assignment within the inflectional stem domain. Nevertheless, there are two cases in which tone is positioned or determined within the larger verb stem that we have not yet introduced. The first case concerns vowel-initial verb roots, which are subject to vowel hiatus that eliminates the OM's tone-bearing unit. The second concerns two subordinate subject constructions that impose their own tone restrictions on macrostem tone. We propose that the verb stem is associated with a different cophonology than that of the the inflectional stem, and that the verb is built up in a hierarchical cyclic fashion with different cophonologies at each stem level.

6.1 VOWEL-INITIAL VERB STEMS WITH OMs. In Moro, vowel hiatus typically results in the deletion of the first vowel. Thus, when a vowel-final OM is attached as a prefix before a vowelinitial root or macrostem prefix, the vowel of the OM is deleted. The $\mathrm{H}$ tone which would have appeared on the vowel of the OM is "orphaned" and forced to appear elsewhere. According to the Stranded Tone Principle (Clements and Ford 1979), tone should be recuperated on the vowel that triggered deletion. However, in Moro, it appears on the vowel in the preceding syllable. Consider the examples in (47). In (47a), the $\mathrm{H}$ tone of the OM appears on the preceding main clause marker $a$-, and in (47b) it appears on the subordinate subject marker $n a-$ (raised to [ $n \Lambda]$ due to vowel harmony in the surface form).
a. /g-a-jé-abatf-a/ $\rightarrow \quad$ [k-á-n-abatf-a $]$ SM.CL-MAIN-1 SG.OM-lift-IMPV 's/he is about to lift me'

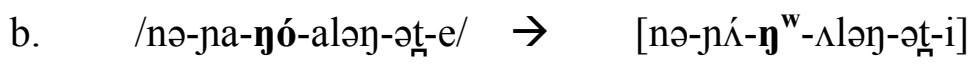 COMP-2PL-3SG.OM-sing-APPL-PROX.CONSEC 'then you all sang to him' 
The $\mathrm{H}$ of the OM prefix is associated outside of the macrostem in these cases, in seeming violation of MSTEM-H/AL(H,L),

One reason for the shift leftwards could be the avoidance of $\mathrm{H}$ tone on a root-initial onsetless light syllable, as described in section 3.1. There is evidence against this analysis: heavy vowelinitial syllables, which generally can bear $\mathrm{H}$ tone, also cause leftward shift, e.g. $g$-áff- $a$ 'he is about to shoot' vs. $g$-á- $n$-aff- $a$ vs. 'he is about to shoot me.'

The leftwards shift of the $\mathrm{H}$ tone of the $\mathrm{OM}$ is therefore due to different pressure than phonotactic avoidance of a $\mathrm{H}$ tone on the initial syllable of the root. Jenks and Rose (2011) attribute the leftward shift to a constraint, MORPHEME DEPENDENCY, which restricts tone that originated on one morpheme from shifting onto a different morpheme within the macrostem. Another interpretation of this restriction is that tone cannot appear on a morpheme that is closer to the root than its point of origin, a restriction on countercyclicity.

Support for a constraint-based analysis of these data comes from the fact that the leftwards shift of $\mathrm{H}$ does not always occur. The $\mathrm{H}$ tone of the OM will appear within the macrostem if there is no available morpheme to its left, such as when the prefix to the left already bears $\mathrm{H}$ tone. In (48a), hiatus occurs between the OM né- and the verb root -alay- in the subordinate verb. The vowel of the OM is deleted, and the H tone appears to the left on the subject marker $a$-, which is low-toned. Note that the applicative marker $-\partial t$ raises all vowels. In (48b), the subject marker is high-toned, and so in this case, the high tone of the OM cannot appear to the left on the subject marker. It appears instead on the first vowel of the root, and downstep occurs between the $\mathrm{H}$ tone of the subject marker, which is in the verb stem, and the H tone of the OM, which is in the macrostem.

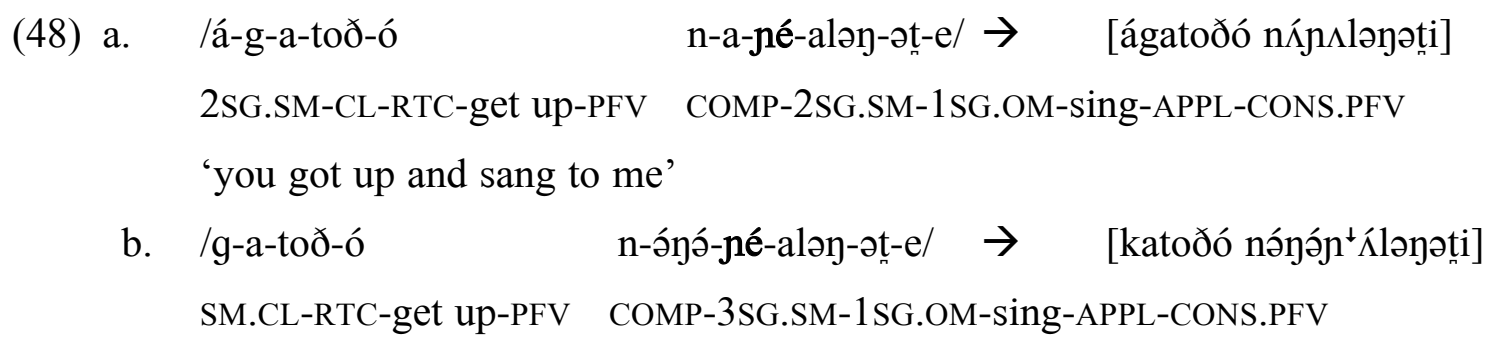
'he got up and sang to me' 
These examples illustrate that $\mathrm{H}$ tone is not deleted, but will appear on the macrostem if there are no positions to the left. Therefore, we maintain that the OM is fronted internal to the macrostem, even though the final position of its tone may depend on availability in the larger verb stem.

Given the examples above, the position of the OM must be fixed at the level of the inflectional stem. The addition of other prefixes interacts with the tone of the inflectional stem in predictable ways. If the adjacent prefix is $\mathrm{H}$ toned, it triggers downstep on the orphaned OM tone. If the adjacent prefix does not bear $\mathrm{H}$ tone, it can then provide a new host syllable for orphaned OM tones. This leftward movement is motivated by morpheme dependency, which prohibits orphaned tones from attaching inside the macrostem. When the prefix preceding the $\mathrm{OM}$ is $\mathrm{H}$ toned, this constraint is overridden due to the unavailability of a new host for the orphaned $\mathrm{H}$ tone. This analysis assumes that at the verb stem level, the constraints MSTEM$\mathrm{H} / \mathrm{AL}(\mathrm{H}, \mathrm{L})$ are ranked lower than MoRPHEME DEPENDENCY, and $\mathrm{H}$ tone shifts to the left if there is an available position, but will not delete due to high-ranked MAX-IO(H).

6.2. SUBJECT MARKER-CONDITIONED TONE PATTERNS. The behavior of subject markers in subordinate verb forms provides another example of how tone requirements at the level of the verb stem can override the requirements of the inflectional stem, but do not alter the position of the OMs. Consider the following consecutive perfective paradigm, with the structure COMP-SMleave-CONS.PFV. The verb tað is a $\mathrm{H}-\mathrm{H}$ verb, and so spreads its $\mathrm{H}$ tone onto the aspect suffix /-e/.

\begin{tabular}{|c|c|c|c|}
\hline $1 \mathrm{SG}$ & íg $\Lambda$ tfánó & n-e-tád-é & 'I got mad and left it' \\
\hline $2 \mathrm{SG}$ & 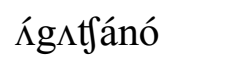 & n-a-táđ-é & 'you got mad and left it' \\
\hline $3 \mathrm{SG}$ & g^tfánó & n-ว́nว́-tª́ð-é & 'he got mad and left it' \\
\hline $1 \mathrm{DU}$ & Álág $\Lambda$ ţánó & n-alə-táð-é & 'we two got mad and left it' \\
\hline $1 \mathrm{IN} . \mathrm{PL}$ & 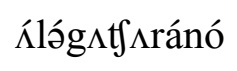 & n-alə-táð-ó-r & 'we all got mad and left it' \\
\hline 1EX.PL & 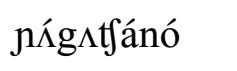 & nə-na-tað-e & 'we (not you) got mad and left it' \\
\hline $2 \mathrm{PL}$ & júg $\Lambda$ tfánó & nə-na-táð-é & 'you all got mad and left it' \\
\hline 3PL & lıtfánó & 1ə-tað-e & 'they got mad and left it' \\
\hline
\end{tabular}

The 1EX.PL and the 3PL both have low-toned macrostems in the subordinate verb. The 1EX.PL subordinate form differs from the 2PL only by the tone pattern on the inflectional stem. This is 
consistent across all subordinate verb stems. This indicates that these particular subject constructions require a specific melodic tone pattern: no $\mathrm{H}$ tone in the macrostem.

However, this requirement affects neither the position of the OM nor its $\mathrm{H}$ tone; the OM is still a prefix in these forms, and still bears $\mathrm{H}$ tone. In fact, the presence of an OM renders the 1EX.PL and 2PL homophonous, since the 3SG OM - yó carries the macrostem $\mathrm{H}$ tone instead of the verb root in the case of $2 \mathrm{PL}$ in (50).

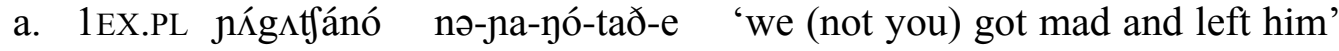
b. 2PL júg $\Lambda$ tfánó
nə--na-yó-tað-e
'you all got mad and left him'

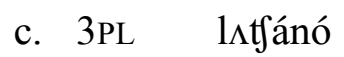
lə-nó-tað̀-e
'they got mad and left him'

In other words, only the inserted default $\mathrm{H}$ tone of the macrostem fails to appear in $(50 \mathrm{~b})$. The OM prefix does not affect the $\mathrm{H}$ tones of other verb stem affixes, such as the complementizer prefix or aspect suffixes. Consider the distinction between consecutive imperfective 2PL trá-ná$w^{\downarrow} a t_{n}-^{\downarrow} o^{\prime}$ '..and then you all are sewing' versus 1EX.PL trá-na-wat-ó '..and then we (not you) are sewing'. The underlying $\mathrm{H}$ tones of the complementizer and aspect suffix are not deleted in the latter form. Only the macrostem default $\mathrm{H}$ fails to appear.

As above, we do not present a formal analysis of these data for lack of space. The basic idea is that the 1EX.PL and 3PL subject markers, which ban $\mathrm{H}$ tone within the verb stem, are associated with alternate cophonologies. Specifically, the same ranking is assumed as for other default verb forms, with the exception that DEP-IO(H) $>>$ MSTEM-H/AL(H,L). This ranking suppresses default tone because it is inserted, but allows underlying $\mathrm{H}$ tones to surface. As candidates with prefixal OMs do not require $\mathrm{H}$ tone insertion, they satisfy MSTEM-H in addition to $\operatorname{AL}(\mathrm{H}, \mathrm{L})$, and thus still optimize the tonal shape of the macrostem.

In summary, these two cases show that there can be additional tone effects at the level of the verb stem, further motivating a domain distinction that was already established on independent grounds in $\S 3$. In both cases, the position of the $\mathrm{OM}$ as a prefix or suffix was shown to be solely dependent on the tonal properties of the inflectional stem.

7. Alternative APPROACHES TO MORO OM ORDERING AND THEIR PROBLEMS. In this section we outline three alternative analyses to the mobility of affix ordering in Moro. The first approach is syntactic: the prefixal OM position is generated by movement, viewed as a copying operation 
(Chomsky 1993). The choice of whether the prefixal or suffix OM is pronounced is regulated by phonology. The second and third approaches are more directly morphological. The second approach, based in Distributed Morphology, analyzes the prefixed position of the OM as arising from an application of Local Dislocation, a morphology-specific movement rule (Embick and Noyer 2001, Embick 2007). The third approach analyzes the difference as arising from subcategorization (Paster 2009). All three alternatives can be shown to overgenerate, the syntactic approach by assuming the prefixal position to be generally available, if not a default position, and the latter two approaches by incorrectly predicting that OMs front in all $\mathrm{H}$-initial macrostems. Additionally, no alternative captures the observation that OM-prefixation is phonologically optimizing, but must stipulate its existence with some additional operaration.

7.1 Movement + Deletion. The first alternative to a phonological analysis of OM placement in Moro would be to analyze the prefixal position as arising from head movement, a process which has been associated with object clitics in Romance (Kayne 1991, Uriagereka 1995), Slavic (Lema and Rivero 1990), and Greek (Terzi 1999). Taking the recent synthesis of this work by Roberts (2010) as an example, we could analyze the preverbal position of Moro OMs as arising due to head-movement of the OM to $v$ :

\section{(51) $\left[{ }_{v P} \mathrm{OM}-\mathrm{V}-V\left[\mathrm{vp}_{\mathrm{P}} \mathrm{V} \mathrm{OM}\right]\right]$}

As in our analysis, the complex head in $v$ is the inflectional stem.

Under the copy theory of movement (Chomsky 1993), the requirement that only one copy of a chain is pronounced is due to linearization principles, which require a strict linear order. The process of CHAIN REDUCTION deletes one of the moved copies (Nunes 2004, p. 27). Under this view, the distribution of the OM in Moro would seem to indicate that Chain Reduction is subject to phonological constraints; in this case, the constraint ranking associated with the macrostem. When this constraint ranking favors the pronunciation of the higher (moved) copy, the lower copy would be deleted, and vice versa.

The problem with the syntactic account is that it predicts that the default position of OMs should be the prefixal one, based on the standard assumption that the leftmost copy generated by movement is preferred (Nunes 2004 and references). However, in section 5 we showed that when OMs fail to alternate, they reliably appear to the right of the verb. A specific example is the low- 
toned third person plural OM - lo, which the syntactic approach predicts should appear at the left edge of the macrostem in cases where such a low tone is allowed, such as in perfective verb forms. More generally, the syntactic analysis incorrectly predicts that the OMs should be pronounced on the right only when they violate some phonological constraint in the macrostem. Instead, the OMs occur to the left only when they are tonally optimizing.

While an account based entirely on syntax makes the wrong predictions, certain patterns that our analysis accounts for might be explicable on syntactic grounds. The most likely case for a syntactic alternative is the positive imperative forms in Moro, which have melodic tone and suffixal OMs. Indeed, many European languages with otherwise regular clitic fronting do not front pronominal clitics in positive imperative forms, a fact which is usually attributed to a higher position of the verb in imperatives (Rivero 1994, Terzi 1999). But even if lack of prefixal OMs in imperatives was attributed to the movement of imperative verbs, a purely movementbased analysis of OM suffers from the same arguments presented in the preceding discussion, namely that non-alternating OMs reliably appear to the right of the verb, indicating that this is their default position.

\subsection{Distributed Morphology AND Local DiSlocation. A second alternative to our} approach is to analyze the variable position of Moro OMs as arising from a morphology-specific affix movement rule, such as LOCAL DISLOCATION in the theory of Distributed Morphology (Embick and Noyer 2001, Embick 2007, 2010). Under such a view, the variable position of Moro OMs would amount to a case of phonologically-conditioned allomorphy (Carstairs 1988). Like the phonologically-driven analysis we argued for in sections 4-6, a Local-Dislocation (LD)based approach could take the postverbal position of the $\mathrm{OM}$ as basic, avoiding the problems with the syntactic account outlined above.

By definition, LD is able to apply within two morphological domains. These domains are derived from syntactic constructs such as head: a maximal syntactic head, whether complex or simple, defines a morphological unit called an M-WORD. If the head is complex (branching) due to head movement, then each head within the maximal head qualifies as a SUBWORD. LD is constrained by these domains: it can manipulate the order of Subwords within an M-Word, or invert the order of M-Words, but cannot place an M-Word inside another M-Word.

By hypothesis, LD has two effects. The first effect, which is optional but still realized with Moro OMs, is to reorder the elements which it applies to. The second effect, a necessary 
component of LD which is also realized in the Moro case, is that the moving element is subordinated or "pushed one step down in the ontology (i.e., what was an M-Word becomes a Subword)" (Embick 2007, p. 320). Applying this approach to Moro, we can take the macrostem to be a complex head, an M-Word, while the OM is a simple head, a trivial M-Word. The subordination component of LD is realized in Moro in that the OM becomes incorporated into the macrostem, participating in its phonological processes such as vowel harmony and in the distribution of tone, as described earlier.

This application of LD is illustrated below for Moro; '+' connects linearized Subwords, ‘^’ connects linearized M-Words (see Embick 2007 for details):

\section{$(52)\left[[\mathrm{V}+v]^{\wedge} \mathrm{OM}\right] \rightarrow[\mathrm{OM}+\mathrm{V}+v]$}

Because it is a rule, the fact that LD is restricted to a subset of OMs is not problematic; the rule can simply list the OMs it applies to, or their features.

Yet providing a structural description for the environments where LD applies in phonological terms is problematic, since default tone patterns are realized in several different ways due to syllable structure. The most likely environment for LD is H-initial macrostems, given that the default tone pattern that corresponds to the prefixal positions of OMs is an initial H. However, this environment overgenerates. First, it faces difficulty in distinguishing between default and melodic initial H. For example, whereas $\mathrm{H}$ melodic tone extends from the AMD suffix across the whole word for all roots, some short CVC roots also extend $\mathrm{H}$ tone onto the final affix, producing the same surface tonal distribution in the inflectional stem: ex. $g$-a-[lág-á] 's/he is about to weed' versus [lág-ó] 'weed!'. Given the criteria of initial H, the all-H distal imperative should trigger LD; but, these imperatives occur only with suffixal OMs (20b). In this case, only reference to the type of aspect/mood/deixis can distinguish the forms, but any syntactic difference between imperatives and declarative verb forms should be irrelevant, as LD is only sensitive to adjacency, a criteria which is clearly met with these imperative forms. The LD analysis could be rescued by establishing the phonological selection for OM postion prior to $\mathrm{H}$ tone spreading, so that melodic has no $\mathrm{H}$ tone in the macrostem, but default does. However, positing an initial $\mathrm{H}$ as the environment for LD faces difficulties in accounting for low-tone initial macrostems that are still default tone forms, namely consonant-only or VC roots, such as $g$-al-a 's/he is about to slice' (sections 3.1, 6.1). These roots still require OM prefixes, despite 
lacking a $\mathrm{H}$ tone at the left edge. The alternative would be to assign default $\mathrm{H}$ tone to all roots before LD applies, and then later delete the $\mathrm{H}$ tone from the $\mathrm{VC}$ roots.

Assuming an environment could be described to trigger LD in Moro, a further claim would be that the $\mathrm{H}$ of the initial OM would then trigger deletion of the macrostem $\mathrm{H}$ which followed it, producing counterfeeding opacity. This requirement underscores another disadvantage of the LD-based approach: not only does it need to stipulate the repositioning of the $\mathrm{OM}$ in Moro, but it fails to capture the generalization that the fronting of the $\mathrm{OM}$ is phonologically optimizing. Instead, the LD approach requires the postulation of an additional rule which creates non-surface true forms. In contrast, the OT approach advocated above not only successfully describes the facts, but does so in an explanatory model where OMs are prefixal due to their role in optimizing macrostem-specific phonology. It does not need to list the specific OMs that can be prefixes; rather this follows from the tonal properties of the OMs themselves.

7.3 SubCATEgorization. A third alternative is to use subcategorization, including phonological subcategorization. As mentioned in the introduction, the notion that phonology can determine morphological order is familiar from some approaches to infixation. In the standard OT analysis of infixation, phonological constraints such as No CODA dictate the position of affixes, pushing prefixes or suffixes within a stem. Yu (2007a,b) argues against this $\mathrm{P}>>\mathrm{M}$ "displacement theory" of infixes (McCarthy and Prince 1993) and in favor of generalized phonological subcategorization, in which infixes subcategorize for prosodic constituents. Such a theory is argued to constrain the interaction between phonology and morphology and maintains a 'morphology precedes phonology' approach. Paster also adopts this model for the behavior of phonologically conditioned suppletive allomorphy $(2006,2009)$ and apparent cases of phonologically conditioned affix order (2005).

With respect to variable or mobile affixes that shift between prefix and suffix, there are also two distinct analytical approaches. Kim $(2008,2010)$ argues that phonological constraints outrank morphological constraints for Huave mobile affixes, and Wolf (2008) also argues for a P >> M approach for mobile affixes, although he rejects Afar, one of the key examples, as a possible case. In contrast, Stump (1993) and Paster (2006, 2009), favor subcategorization approaches to morphological position, and suggest that mobile affixes have allomorphs with distinct subcategorization frames. 
Under a subcategorization analysis, affixes subcategorize for syntactic, semantic and phonological features within the morphological component. Phonological elements include members of the prosodic hierarchy (mora, syllable, foot) as well as consonant and vowel (Paster 2009 further proposes consonants and vowels specified with particular phonological features). The subcategorization frame may also specify the location of an affix relative to the stem and other elements. Affix ordering under this approach is assumed to follow from scope, the mirror principle (Baker 1985) or specific templates. A subcategorization approach to 'mobile affixation' requires positing either two distinct subcategorization frames for a single affix (see discussion in Stump 1993) or two affixes that subcategorize for different locations (Paster 2009), but which must be stipulated to be in complementary distribution. For Moro, a high-toned OM would subcategorize for particular tone properties of the stem (a single $\mathrm{H}$ tone within the macrostem) or be realized elsewhere at the right edge of the verb stem. Alternatively, there could be two separate affixes with the same morphosyntactic features, but with different subcategorization frames, as shown in (53)

$$
\begin{aligned}
& \text { Single affix } \\
& \text { yó SYNSEM: } 3 \text { sgOM } \\
& {[\text { m-stem__ }[\text { dstem } \mathrm{H}]]} \\
& {[\text { verbstem }] \_ \text {elsewhere }}
\end{aligned}
$$

$$
\begin{aligned}
& \text { Two affixes } \\
& \text { yó_SYNSEM: } 3 \text { sgOM } \\
& \text { [ m-stem__ [dstem } \mathrm{H}]] \\
& \text { yó SYNSEM: } 3 \mathrm{sgOM} \\
& \text { [verbstem }]
\end{aligned}
$$

Each type of analysis proves to be problematic both empirically and theoretically. On the empirical side, there is no clear way to reference the default $\mathrm{H}$ tone and clearly distinguish it from the all $\mathrm{H}$ melodic tone, as discussed above for Local Dislocation. Furthermore, the same problem of $\mathrm{VC}$ roots that lack $\mathrm{H}$ tone in default tone cases arises. In the Cophonology analysis, default and melodic forms which have identical tone patterns on the surface are distinguished through constraint rankings associated with each morphological category; the position of the OM follows from these overall rankings, not from the way tone is specifically realized in in a particular stem without an OM.

From a theoretical point of view, positing two separate, identical OMs that appear in different environments would be a suspicious coincidence, as $\operatorname{Kim}(2008,2010)$ argues. A single affix with different phonological subcategorization environments does recognize this issue, but misses 
the generalization that affix mobility is phonological optimizing, and, like the Distributed Morphology LD analysis, further requires deletion of the $\mathrm{H}$ tone on the stem in default tone cases. The Cophonology analysis further predicts that non-alternating forms such as 3PL $-l o$ should not alternate based on their tonal properties, a fact which would simply be listed alongside the other subcategorization frames in the subcategorization approach. We take these issues to conclusively favor the phonologically driven approach to OM placement.

\subsection{OTHER CASES OF PHONOLOGICALLY-CONDITIONED MOBILE AFFIXES}

Besides Moro, two cases of phonology dictating prefix or suffix position have been reported in the literature: Huave, illustrated in the introduction, and Afar. Both involve affixes being variable in accordance with syllable structure and initial segments of the stem. We provide a brief outline of Huave and Afar here, and discuss why they constitute legitimate cases. We conclude by arguing that variable affixation can be determined by phonology, and by extension, the Moro case of OM placement according to tone. We then speculate on the rarity of such cases.

7.4.1 Huave. Kim (2008, 2010) prevents an analysis of San Francisco del Mar Huave mobile affixes. Huave has six consonantal mobile affixes (stative $-\mathrm{n}-$, completive $-\mathrm{t}-$, subordinate $1^{\text {st }}-\mathrm{n}$-, subordinate $-\mathrm{m}-, 2^{\text {nd }}$ intransitive $-\mathrm{r}-$ and $\left.1^{\text {st }}-\mathrm{s}-\right)$ that are positioned as prefixes or suffixes for phonological reasons: to avoid consonant clusters and epenthesis, regardless of the morphosyntactic properties of the stem. Similar cases were also discussed in Noyer (1994) for San Mateo del Mar Huave. Consider the position of the mobile affixes -s- and -m- below:

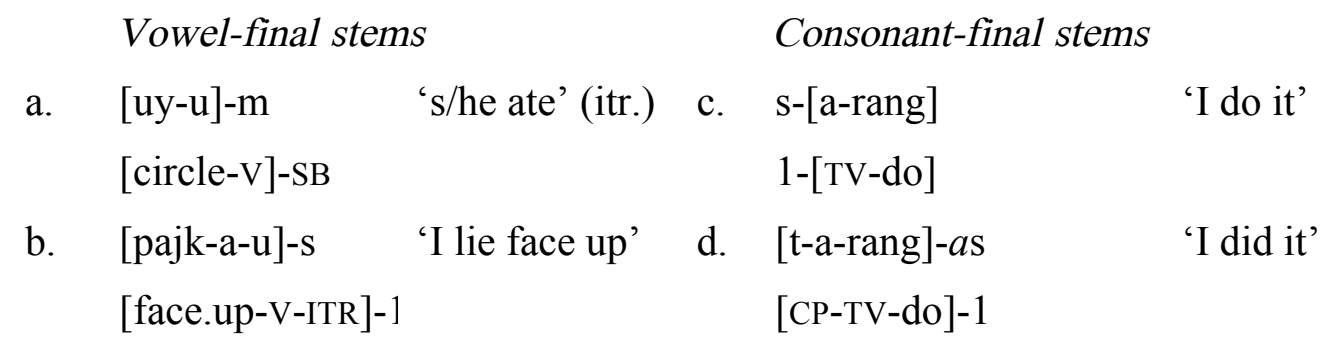

Kim argues that suffixation is the default pattern (produced by a constraint ALIGN-R), but that the affixes will be shifted to prefix position to avoid consonant sequences and the creation of a complex coda. In (54a) and (54b), the stems end in a vowel, and therefore a suffix is found. In 
(54c), the stem ends in a consonant, so to avoid a consonant cluster, the -s- appears as a prefix. This is sanctioned as the stem is vowel-initial. If the prefix position does not improve syllable structure, as with consonant-initial stems, epenthesis of [a] occurs, as in (54d). Kim argues that this analysis is preferable to one that relies on subcategorization. For Huave, a prefix would subcategorize for a vowel-initial stem, whereas the suffix would be the elsewhere case (Kim 2010). The fact that both affixes are segmentally identical, have the same meaning, and appear in complementary environments is a coincidence in the subcategorization analysis. Kim further argues that this approach also misses the generalization that affix mobility optimizes syllable structure.

Paster's (2009) solution to Huave is to propose that it has fixed C and V positions, but segments are allowed to 'float' and associate from left-to-right within subscribed levels. There is no independent motivation for such a proposal except to avoid a phonological analysis of affix ordering. Kim notes that her analysis directly specifies the morphological location of the affixes within subscribed morphological levels. It is only within these levels that there is phonologicallydetermined prefix or suffix positioning. By constraining the creation of these positions morphologically, such an analysis avoids criticisms of overgeneration leveled against $\mathrm{P}>\mathrm{M}$.

7.4.2 AfAR. Afar presents another example of mobile affixes, as analyzed in Fulmer (1991) and Rucart (2006). Afar has two main verb types, labeled Class I and Class II (Parker and Hayward 1985), and several 'mobile affixes' which appear as either prefixes or suffixes. Class I verbs, which condition prefixes, begin with a vowel /e o i u/ ex. edeg-e 'I knew' while Class II verbs, which condition suffixes, begin with a consonant or /a/, ex. fak-e 'I opened' or alif-e 'I closed'. Mobile affixes include subject markers (/t- j- n-/), the causative (/s/), benefactive (/t/) and passive $(/ \mathrm{m} /)$ markers. The subject marker -t- appears as a prefix with Class I: ex. $t$-edeg-e 'you/she knew', but as a suffix with Class II: fak-t-e 'you/she opened' or alif-t-e 'you/she closed'. The phonological aspect of their distribution resembles that of Huave in that prefixes appear with stems that are vowel-initial. Unlike Huave, in Afar stems that begin with the vowel [a] do not trigger prefixation. Otherwise, with consonant-initial and [a]-initial stems, suffixes occur. Bliese (1973) argues that the a-initial stems were historically ?-initial, in which case the division would have been based on a strict consonant-initial vs. vowel-initial division. Today, however, the system is not so clear-cut. In fact, Afar is undergoing further change. The division of Class I/Class II is no longer perfectly divided based on initial vowel. While all a-initial verbs 
are suffixing, other vowel-initial verbs are also suffixing, as a verb count based on the Parker and Hayward (1985) dictionary reveals:

\begin{tabular}{cccccc}
\hline initial root $V$ & $a$ & $e$ & $o$ & $i$ & $u$ \\
\hline Class I & 0 & 76 & 27 & 126 & 77 \\
Class II & 119 & 6 & 16 & 22 & 21
\end{tabular}

Dialectal evidence (Bliese 1973) also suggests that Afar is undergoing a shift towards using suffixes, even with verbs that are vowel-initial.

Although Afar has the historical hallmarks of a phonologically-dependent mobile affix system, language change has caused a breakdown in the consonant vs. vowel conditioning distinction. The shift towards suffixation has further caused the Class I/II distinction to be morphologized. Synchronically, then, Wolf (2008) is right that there are issues with treating Afar mobile affixes as phonologically-conditioned. Diachronically, however, it appears to have been driven by similar syllable structure constraints to Huave.

7.5. RARE BUT ATTESTED. The Moro mobile affix cases shares certain similarities with those found in Huave and Afar. First, they all appear to favor suffixation as the default case. Prefixation occurs for phonological reasons: to satisfy $\mathrm{H}$ tone requirements in Moro and to satisfy syllable structure requirements in Huave and Afar. Second, the mobile affixes constitute only a subset of verbal affixes which share a common phonological make-up (a single consonant for Huave and Afar (with epenthetic vowels); a single CV syllable with $\mathrm{H}$ tone for Moro). Moreover, their phonological make-up connects directly with the phonological constraints on their realization. Third, they are constrained morphologically. The Afar morphemes are subject markers and 'extension' markers, appearing closest to the verb root. In Huave, Kim shows how the morphemes are restricted to two inner morphological levels. In Moro, the mobile affixes are object markers that attach to the inner macrostem. Their positions do not break-up morphemes, as in the case of infixation or metathesis. They do not 'float' in the sense of featural morphemes, being able to attach to different segments. Rather, their basic position adjacent to the verb is determined by morpho-syntax, while the realization in the prefixal position is due to the phonology of a morphologically delimited domain. In fact, such an analysis may not be at odds with Paster (2009)'s claim that affix placement can be affected by phonology via 
subcategorization for phonological elements, but this will produce only local effects (e.g. infix placement) rather than radical 'reshuffling' of multiple morphemes for phonological wellformedness. While mobile affixes are not strictly local in terms of adjacency, they are hierarchically local in the context of the morphological structure of the verb stem. That is, whether an affix associates as a prefix or suffix, it is still positioned at the edge of a particular domain, and ordered linearily in the same fashion with respect to the root and other affixes. For example, the Afar extension markers suffix to the verb root, followed by the subject markers. When they are prefixes, the subject markers precede them. In Huave, Kim shows how the verb is structured in layers, like the Moro verb, and the mobile affixes attach within prescribed layers.

As to the reliance on tone as a phonological condition, this is more unexpected, since tone systems tend to be variable in lexical specification and distribution. However, note that default $\mathrm{H}$ tone in the Moro verb system, which conditions prefixation, is predictable in position and appearance, in a manner more common in stress systems. As infixes can depend on stress for their position, it is not inconceivable that consistent tone in a predictable position could also motivate infixation. However, a language must have all of the necessary conditions in place in order for affix mobility to optimize prosodic structure in this way.

Although rare, mobile affixes are attested in the world's languages, and are observed in languages belonging to different language families. Analyses seeking to explain them in their own right highlight the role of phonology. Analyses that seek to explain them away because they do not fit a unified theory of phonology/morphology interaction prove unexplanatory. Our position is that it is possible for phonology to constrain morpheme position, and we have attempted to construct the best possible analysis of this interaction, using a $\mathrm{P}>\mathrm{M}$ analysis, where $\mathrm{M}$ constraints are construed as morpho-syntactic, formulated with reference to morphosyntactic (verb stem/verb phrase) domains. This is in line with other approaches to rare phenomena in language, as outlined in Harris (2010). Harris argues that many examples of rare morpho-syntactic structures are the result of a complex combination of changes and conditions. Although uncommon, such structures are attested, and often endure, and grammatical analyses need to accommodate them.

Affixes generally appear in particular positions on a consistent basis. While it is possible that the prefix OM position in Moro may have historically arisen due to morpho-syntactic reasons, such as an auxiliary that may have eroded with the one non-dependent verb form (proximal imperfective), the current motivation for alternate positions appears to be phonological. The 
different OM positions now serve to demarcate the boundaries of morphological domains within the verb. Related Kordofanian languages such as Tira (Stevenson 2009), Otoro (Stevenson 2009) and Cwaya (Guest 1998) also show mobile positioning of person/number markers, but allow more than one affix to be prefixed. However, little is know about the tone systems of these languages. In Cwaya, suffixes do co-occur with the low-toned verb form (present), whereas prefixes co-occur with verb forms with lexical $\mathrm{H}$ tone (past and future), a similar type of distribution to Moro, but the available data only lists three verb form types. If these systems evolved from a different conditioning strategy, but the tone and the position of OMs is now used to mark prosodic constituents, we expect such cases to arise only under particular circumstances, and to be far from common.

8. Conclusion. In this paper we have presented novel data on the position of object markers in the Thetogovela dialect of Moro, an underdocumented Kordofanian language of Sudan. While we have shown that the positions of object markers in Moro as either prefixes or suffixes correlate with certain aspect/mood/deixis of verb forms, we argued that the positions do not follow from clearly generalizable morpho-syntactic characteristics of the verb forms. The positions do, however, neatly follow from the tonal properties of these particular verb forms. We analyze the object marker positions as following from restrictions on the distribution of tone. If a verb form requires a particular melodic tone pattern, object markers are suffixes. On the other hand, if a verb form adopts a default, phonologically-predictable pattern, then object markers appear as prefixes. The tone property of the object markers themselves also dictated their appearance as prefixes. Only a single $\mathrm{H}$ toned object prefix is allowed, whereas low-toned and additional object markers appear as suffixes. Although such phonologically-determined patterns of affix position are rare in the world's languages, the Moro case underscores the need to accept them as real and incorporate them into the architecture of linguistic theory.

\section{REFERENCES}

Anderson, Stephen R. 2005. Aspects of the Theory of Clitics. Oxford: Oxford University Press. ANTTILA, ARTO. 2002. Morphologically conditioned phonological alternations. Natural Language and Linguistic Theory 20. 1-42. 
AntTILA, ARTO. 2009. Derived environment effects in colloquial Helsinki Finnish. The nature of the word:Essays in honor of Paul Kiparsky, ed. by Kristin Hanson and Sharon Inkelas, 433460. Cambridge: MIT Press.

BAKer, MARK. 1985. The Mirror Principle and Morphosyntactic Explanation. Linguistic Inquiry 16. 373-415.

BiCKMORE, LeE. 2000. Downstep and fusion in Namwanga. Phonology 17. 297-331.

Bickmore, LeE. 2007. Stem Tone Melodies in Cilungu. SOAS Working Papers in Linguistics Vol. 15. 7-18

Black, Mr. And Mrs. K. 1971. The Moro Language, Grammar and Dictionary. Khartoum : University of Khartoum (Faculty of Arts).

Bliese, LOREN. 1973. Notes on the Reconstruction of Glottal Stop in the Aussa Dialect of 'Afar. Anthropological Linguistics 15: 373-382

Bonet, EulÀliA. 1995. Feature structure of Romance clitics. Natural Language and Linguistic Theory 13. 607-47.

CABallero, Gabriela. 2010. Scope, phonology and morphology in an agglutinating language: Choguita Rarámuri (Tarahumara) variable suffix ordering. Morphology 20. 165-204.

CHOMsky, NoAm. 1993. A minimalist program for linguistic theory. In The view from building 20: Essays in linguistics in honor of Sylvain Bromberger, ed. by Kenneth Hale and Samuel Jay Keyser, 1-52. Cambridge, Mass.: MIT Press.

Chomsky, NoAm. 2000. Minimalist inquiries: The framework. In Step by step: Essays on minimalist syntax in honor of Howard Lasnik, ed. By Roger Martin, David Michaels, and Juan Uriagereka, 89-155. Cambridge, Mass.: MIT Press.

Clements, George nicK And KeVen C. FORD. 1979. Kikuyu Tone Shift and Its Synchronic Consequences. Linguistic Inquiry 10. 179-210.

Curnow, Timothy Jowan. 1999. Maung verbal agreement revisited: A response to Donohue (1998). Australian Journal of Linguistics 19.2. 141-59.

Dimmendahl, Gerrit. 2009. Tima. Coding participant Marking. Construction types in 12 African languages, ed. by Gerrit Dimmendaal, 331-54. Amsterdam: John Benjamins.

DurANTI, AlesSANDro. 1979. Object clitic pronouns in Bantu and the Topicality Hierarchy. Studies in African Linguistics 10, 31-45.

EBERT, KEREN. 1979. Sprache und Tradition der Kera (Tschad), Teil III: Grammatik. Berlin: Dietrich Reimer. 
EMBICK, DAVID. 2007. Linearization and Local Dislocation: Derivational mechanics and interactions. Linguistic Analysis 33, 303-336.

EMBICK, DAVID and Rolf NOYER. 2003. Movement operations after syntax. Linguistic Inquiry 32, 555-595.

FASSI FEHRI, ABDELKADER. 1993. Issues in Arabic clauses and words. Dordrecht: Kluwer.

FULMER, S. LEE. 1991. Dual-position affixes in Afar: an argument for phonologically-drivent morphology. The Proceedings of the West Coast Conference on Formal Linguistics 9, ed. by In Aaron Halpern, 189-203. Stanford: CSLI.

Gibbard, George, Hannah Rohde and Sharon Rose. 2009. Moro Noun Class Morphology. Selected Proceedings of the 38th Annual Conference on African Linguistics, ed. by Masangu Matondo, Fiona Mc Laughlin, and Eric Potsdam, 106-117. Somerville, MA: Cascadilla Proceedings Project.

GoOD, JEFF. 2007. Strong linearity, weak linearity, and the typology of templates. New challenges in typology: Broadening the horizons and redefining the foundations, ed. by Matti Miestamo and Bernhard Waelchli, 11-33. Berlin: Walter de Gruyter.

Guest, ElizABeth. 1998. Cwaya pronouns. Manuscript. Available at http://www.rogerblench.info/Language\%20data/Niger-Congo/Kordofanian/Cwaya/ Hargus, Sharon AND Siri G. TutTle. 1997. Augmentation as affixation in Athabaskan languages. Phonology 14. 177-220.

Harley, Heidi, AND Elizabeth RitTer. 2002. Person and Number in Pronouns: A FeatureGeometric Analysis. Language 78. 482-526.

HARRIS, AliCE. 2010. Explaining Typologically Unusual Structures: The Role of Probability. Rethinking Universals: How Rarities Affect Linguistic Theory, (Empirical Approaches to Linguistic Typology, 45), ed. by Jan Wohlgemuth and Michael Cysouw, 91-103. Berlin/ New York: de Gruyter Mouton.

HEAP, DAVID. 2005. Constraining optimality: Clitic sequences and Feature Geometry. Clitic and Affix Combinations, ed. by Lorie Heggie and Francisco Ordóñes, 81-012. Amsterdam: John Benjamins.

HyMAn, LARRY. 2003. Suffix ordering in Bantu: a morphocentric approach. Yearbook of Morphology 2002, 245-81.

HyMAN, LARRY, AND ARMindo NGUNGA. 1994. On the non-universality of tonal association 'conventions': evidence from Ciyao. Phonology 11. 25-68. 
Hyman, LARry, AND Alessandro DurAnti. 1982. On the Object Relation in Bantu. Syntax and Semantics 15 Studies in Transitivity, ed. by Paul Hopper and Sandra Thompson, 217-39. New York: Academic Press.

InKelas, SHARON. 1993. Nimboran Position Class Morphology. Natural Language and Linguistic Theory 11. 559-624.

InKELAS, SHARON, and Cheryl Zoll. 2007. Is Grammar Dependence Real? Linguistics 45, 133-71.

Jenks, Peter And Sharon Rose. 2011. High Tone in Moro: Effects of Prosodic Categories and Morphological Domains. Natural Language and Linguistic Theory 29. 211-50.

Jenks, Peter And Sharon Rose. 2009. Syllable weight and high tone in Moro. Proceedings from the $45^{\text {th }}$ Annual Meeting of the Chicago Linguistic Society. to appear.

KAYNE, RICHARD S. 1991. Romance clitics, verb movement, and PRO. Linguistic Inquiry 22, 647-686.

KIM, YUnI. 2008. Topics in the Phonology and Morphology of San Francisco del Mar Huave. Berkeley, CA: University of California, Berkeley Dissertation.

KIM, YUNI. 2010. Phonological and morphological conditions on affix order in Huave. Morphology 20. 133-63.

LEGENDRE, GÉRALDINE. 2000. Positioning Romanian clitis in PF: an Optimality-Theoretic analysis. Clitics in Phonology, Morphology and Syntax, ed. by Birgit Gerlach and Janet Grijzenhout, 21954. Amsterdam: John Benjamins.

LEMA, JosÉ and MARÍA-LUISA RIVERO. 1990. Long head movement: ECP vs. HMC. In Proceedings of NELS 20, 333-347. UMass, Amherst: GLSA

MCCARThy, John J. and Alan PRINCE. 1993. Prosodic Morphology I: Constraint Interaction and Satisfaction. Technical Report \#3, New Brunswick, NJ: Rutgers University Center for Cognitive Science.

McCarthy, John J., Kevin Mullin, and Brian W. Smith. 2012. Implications of Harmonic Serialism for lexical tone association. In Phonological Explorations. Empirical, Theoretical and Diachronic Issues. Ed. Bert Botma \& Roland Noske. Berlin: De Gruyter. 265-297.

Mutaka, Ngessimo and Larry Hyman. 1990. Syllable and morpheme integrity in Kinande reduplication. Phonology 7. 73-120.

Myers, ScotT. 1987. Tone and the Structure of Words in Shona. Ph.D. dissertation, University of Massachusetts, Amherst. 
MYers, SCOTT. 1997. OCP effects in Optimality Theory. Natural Language and Linguistic Theory 15. 847-92.

NEVINS, ANDREW. 2007. The representation of third person and its consequences for person-case effects. Natural Language and Linguistic Theory 25. 273-313

NoYer, Rolf. 1994. Mobile affixes in Huave: optimality and morphological wellformedness. The Proceedings of the West Coast Conference on Formal Linguistics 12, ed. by Eric Duncan, Donka Farkas, and Philip Spaelti, 67-82. Stanford, CA: CSLI.

Odden, DAVID. 1986. On the role of the Obligatory Contour Principle in phonological theory. Language 62. 353-83.

OdDen, DAVID. 1989. Predictable tone systems in Bantu. Autosegmental studies on pitch accent systems, ed. by Harry van der Hulst and Norval Smith, 225-251. Dordrecht: Foris.

OdDen, DAVID. 1990. Tone in the Makonde dialects: Chimahuta. Studies in African Linguistics 21, 149-187.

OdDen, DAVID. 1996. The phonology and morphology of Kimatuumbi. Oxford University Press: Oxford.

PARKER, ENID AND RICHARD HAYWARD. 1985. Afar-English-French dictionary with Grammatical Notes in English. London: School of Oriental and African Studies

PASTER, MARY. 2005. A survey of phonological affix order with special attention to Pulaar. Proceedings of the 35th Annual Meeting of the North Eastern Linguistic Society, ed. by Leah Bateman and Cherlon Ussery, 491-506. Amherst, MA: GLSA.

PASter, MARY. 2006. Phonological conditions on affixation. PhD Dissertation, UC Berkeley.

PASTER, MARY. 2009. Explaining phonological conditions on affixation: Evidence from suppletive allomorphy and affix ordering. Word Structure 2.1. 18-47.

PerlmutTER, DAVID. 1971. Deep and surface structure constraints in syntax. New York: Holt, Rinehart and Winston.

RICE, KEREN. 2000. Morpheme order and semantic scope: word formation in the Athapaskan verb. Cambridge: Cambridge University Press.

Rivero, MARIA Luisa. 1994. Clause structure and V-movement in the languages of the Balkans. Natural Language and Linguistic Theory 12, 63-120.

Rose, SHAROn. to appear. The morphological structure of the Moro verb. Nuba Mountain Language Studies, ed. by R. Blench and T. Schadeberg (eds.) Cologne: Rüdiger Kõppe. 
Rose, Sharon, Farrell Ackerman, George Gibbard, Peter Jenks, Laura Kertz, And

HANnAH RoHDE. Wh-question constructions in Moro. Unpublished ms., UC San Diego, UC

Berkeley, Brown University, and University of Edinburgh.

RUCART, PIERRE. 2006. Templates from syntax to morphology: affix ordering in Qafar.

Proceedings of the ISCA Tutorial and Research Workshop on Experimental Linguistics, ed.

by A. Botinis, 213-216. ISCA and the University of Athens.

SELKIRK, ELISABETH. 1995. The prosodic structure of function words. In Papers in Optimality Theory, ed. by Jill Beckman, Laura Walsh Dickey, and Suzanne Urbanczyk, 439-70. Amherst, MA: GLSA Publications.

SilversteIn, MichaEL. 1976. Hierarchy of Features and Ergativity. Grammatical Categories in Australian Languages, ed. by R.M.W. Dixon, 112-71. Canberra: Australian Institute of Aboriginal Studies.

Stevenson, Roland. 2009. Tira and Otoro. Two Kordofanian Grammars. ed. by Thilo Schadeberg.

Köln: Rüdiger Köppe Verlag.

STUMP, GREGORY. 1993. Position classes and morphological theory. In Yearbook of Morphology 1992, ed. by Geert Booij \& Jaap van Marle, 129-180. Dordrecht: Kluwer.

STUMP, GREGORY. 1997. Template morphology and inflectional morphology. Yearbook of

Morphology 1996, ed. by Geert Booij and Jaap van Marle, 217-241. Dordrecht: Kluwer.

TERZI, ARHONTO. 1999. Clitic combinations, their hosts, and their ordering. Natural Language and Linguistic Theory 17, 85-121.

URIAGEREKA, JUAN. 1995. Aspects of the syntax of clitic placement in Western Romance. Linguistic Inquiry 26, 79-123.

Wolf, Matthew. 2008. Optimal Interleaving: Serial Phonology-Morphology Interaction in a Constraint-Based Model. Amherst, MA: University of Massachusetts, Amherst dissertation. Yu, Alan. 2007a. A natural history of infixation. Oxford University Press.

Yu, ALAN. 2007b. The phonology-morphology interface from the perspective of infixation. New challenges in typology: Broadening the horizons and redefining the foundations, ed. by Matti Miestamo and Bernhard Wälchli, 35-54. Berlin: Mouton de Gruyter.

ZWICKY, ARNOLD. 1970. Auxiliary reduction in English. Linguistic Inquiry 1. 323-336. 